\title{
Rend és rendetlenség 1918-1919-ben
}

\section{HATOS Pál ${ }^{1}$}

\begin{abstract}
A tanulmány a magyar társadalom történetét tárgyalja 1918 ősze és 1919 tavasza között, az őszirózsás forradalomtól a Magyarországi Tanácsköztársaság kikikáltásáig. Részletesen elemzi az I. világháború és az összeomlás, valamint a kettős monarchia megszünését követő zavaros forradalmi időszak káoszát, a közigazgatás időleges széthullásának következményeit, az l. világháborús katonatömegek és a szegény agrárnépesség amorf és ideológiamentes mozgalmait, a bolsevizmus magyarországi megjelenését és széles körü társadalmi hatását. Az elemzés módszere az úgynevezett sürü leírás és egyfajta tudatos igyekezet, hogy ne a következmények, hanem az okok felöl vizsgáljuk az I. világháború utáni háborús időszak eseményeit, a rend és rendetlenség megbomlott viszonyrendszerét.
\end{abstract}

Kulcsszavak: I. világháború, háborús vereség, erőszak, összeomlás, őszirózsás forradalom, proletárdiktatúra, parasztforradalom, kommunizmus

\section{Bevezetés}

1918. október közepétől a magyar politika a lefagyás állapotában volt. A négy éven át változó szerencsével folyó háború kimenetele hirtelen egyértelmúvé lett. Az uralkodó IV. Károly, osztrák császárként előre futott: október 16-án kihirdette az Osztrák-Magyar Monarchia nyugati felének föderalizációját. Akiknek szólt, azonban már nem fogadták el, a csehek, lengyelek, szlovének, horvátok, szerbek, románok, ukránok - legalábbis a politikailag tudatossá lett középosztályi csoportjaik, s legfőként politikai vezetőik - mind-mind új nemzetállamokat akartak építeni a Monarchia romjain, akár egymás rovására is. Egy pillanat alatt kiderült, a kiáltvány nem egy megújult birodalom keresztlevele, hanem a dualizmus halotti bizonyítványa lett. Ifjabb Andrássy Gyula az uralkodó döntését ahhoz az öngyilkoshoz hasonlította, aki azért öli meg magát, nehogy más tegye meg ezt vele. ${ }^{2}$ A proklamáció ugyan Magyarországra nem terjedt ki, az uralkodói döntés miatt azonban fél évszázad egész magyar politikája került légüres térbe egyik napról a másikra. Tisza István az uralkodói manifesztum másnapján a magyar országgyülés nyilvánossága előtt beismerte az igazságot: „[E]zt a háborút

\footnotetext{
Dr. Hatos Pál, Nemzeti Közszolgálati Egyetem Eötvös József Kutatóközpont, Közép-Európa Kutatóintézet, tudományos főmunkatárs, intézetvezető.

Pál Hatos PhD, University of Public Service Eötvös József Research Center Institute of Central European Studies, Head of Institute, senior research fellow.

E-mail: hatos.pal@uni-nke.hu

2 Andrássy Gyula: Diplomácia és világháború. Budapest, Gönczöl-Primusz, [1920.] 1990. 165.
} 
elvesztettük.” Másfél éve nem volt már kormányfő, de továbbra is a legfontosabb magyar politikus, akinek végzetes szavát mégis „robbanóanyagként” hintették ki a frontokon, s néhány nap múlva „mint a pelyva a szél szárnyán, úgy röpültek szanaszét a legjobb csapatok is". ${ }^{3}$ Wekerle Sándor miniszterelnök háromszor mondott le három hét alatt, október 29-ig mégis ügyvezető kormányfő maradt. Utódjának, az egynapos miniszterelnöknek, Hadik János grófnak csupán annyit hagyott hátra, hogy az október 31-én hajnalban papucsban és hálóingben adja át a történelmi Magyarországot Károlyi Mihálynak és az általa vezetett, alig egy héttel korábban létrehozott Nemzeti Tanácsnak. Tisza visszavonult, magányosan várta be végzetét városligeti villájában, s plakátokat tépdesett a korán sötétedő pesti éjszakában. „Hát jöjjön Károlyi!” - írta október utolsó napján a Budapesti Hírlap, amely előző számaiban is még egyre Károlyi alkalmatlanságát, felelőtlenségét ostorozta.

Az Osztrák-Magyar Monarchia hadereje hihetetlen gyorsan, szinte órák alatt esett szét 1918 októberének utolsó napjaiban. Idegen földön, mert sem Ausztria, sem Magyarország földjén nem volt ellenség, a hadsereg az összes arcvonalon mindenütt ellenséges területen állott. Ám a katonák hazavágytak, a messzi harctereken létrejött frontközösség nem vágta el a katonát az otthon hagyott világtól. Lélekben semmiképp. A távoli hadszíntér nem is volt olyan távol, front és hátország azelőtt soha nem tapasztalt kölcsönhatást mutatott. A háborús levelezések mutatják, hogy az otthon iránti egyre növekvő nosztalgia és az otthoniakért érzett aggódás legalább annyira befolyásolta az egyszerű katona érzéseit és viselkedését, mint a lövészárkokban létrejött bajtársi közösség. ${ }^{4}$ Szurmay Sándor honvédelmi miniszter visszaemlékezése szerint a frontkatonaság értetlenül szemlélte, hogy miért nem lehet befejezni a háborút, ha ellenséges földön állunk, s „már oly fényesen megvertük a muszkát, szerbet, a románt és a taliánt is?". ${ }^{5}$ Valóban, ha csak a térképre pillantunk, 1918 őszén a Monarchia minden lehetséges hadicélja teljesült: Szerbia, Románia leverve és megszállva, Olaszország visszaszorítva, a bolsevik Oroszország pedig a békéért cserébe kontinensnyi területeteket adott át Breszt-Litovszkban a központi hatalmaknak. De milyen áron? A győzelem mértékét már az ókor óta a zsákmány nagysága fejezte ki. A mohóság most sem hiányzott, de egyetlen adat elég arra, hogy lássuk, mennyire keveset értek a látszólag kedvező hadászati pozíciók. A megszállt Ukrajna végtelen búzaföldjeiről a remélt élelmiszer alig 1\%-át sikerült begyüjteni 1918 nyarán. ${ }^{6}$ Az éhező hadsereget már nem ösztönözte győzelmi akarat - a legfőbb hadúr, a király beleőszült az 1918. júniusi irtózatos emberveszteségekkel járó piavei csatavesztés hírébe -, a katonaság maga üzent

\footnotetext{
Zalavármegyei bolsevik mozgalom története IV. hadügy, MNL MOL K46 PTI 605 f. II/35/II kötet, 106.; lásd még: Hegedűs Loránt: Két Andrássy és két Tisza. Budapest, Athenaeum, 1941. 358.

4 A kérdés irodalmához lásd: Michael Roper: Nostalgia as an Emotional Experience in the Great War. The Historical Journal, 54. (2011), 2 421-451.

5 Szurmay Sándor visszaemlékezése. MNL MOL K440 PTI 607f, 37, 1.

6 Siklós András: Adalékok az Osztrák-Magyar Monarchia belső helyzetéhez 1918 tavaszán és nyarán. Történelmi Szemle, 26. (1983), 1.4.
} 
hadat a háborúnak. „Aludni, semmivel sem törődni, fel se ébredni, amíg ennek az őrületnek vége nem lesz" - jellemezte a kopár sziklák fedezékében kushadó magyar bakák lelkiállapotát a későbbi népi író, Veres Péter, még később Rákosi Mátyás kegyelméből „csizmás hadügyminiszter”, ekkor még maga is frontra kihajtott közlegény. ${ }^{8} \mathrm{Az}$ olasz fronton korábban is előfordult, hogy a havasra mászás közben a kimerült, fagyott lábú katonák hátrafelé tüzeltek a gyúlölt parancsot kiadó tisztjeikre. ${ }^{9}$ De 1918 szeptemberében a morál már olyan bizonytalan volt, hogy a frontra indított csapatok jelentékeny részét töltény, esetleg fegyver nélkül vagonírozták be, hogy út közbeni randalírozásukat, fosztogatásaikat megakadályozzák. ${ }^{10}$ Egy Ungvárról elindított menetszázadból, mire a vonat Sátoraljaújhelyre ért, csupán hárman maradtak, a többiek leugrottak, elszökdöstek. ${ }^{11} \mathrm{~A}$ háború utolsó évében a hadsereg több mint fele már nem a frontokon harcolt, mivel egyre nagyobb létszámú karhatalomra volt szükség a hátországban a lakosság és a többi katona, illetve főként a rohamosan növekvő számú katonaszökevények féken tartására. ${ }^{12}$

$\mathrm{Az}$ összeomlás robaja egyre hangosabb volt a hátországban is. A háború egyre fokozódó arányai mind több munkaerőt vontak el a termeléstől, miközben a korlátozott termelés eredményeire a hadsereg egyre nagyobb igényt tartott. Mindez a kereslet és kínálat békebeli egyensúlyának megbomlását és ennek folytán az árak ugrásszerű emelkedését eredményezte. ${ }^{13}$ Teleszky János pénzügyminiszter számításai szerint a háborús négy év 30 esztendő jövedelmét emésztette el. ${ }^{14}$ 1918-ban a kimerülés és nélkülözés egyre általánosabban járta át a társadalom széles rétegeit. Október 25-én éjjel a keménykezű Lukachich Géza báró altábornagyot nevezték ki a budapesti helyőrség parancsnokának, akitől a rend minden eszközzel való helyreállítását remélték. ${ }^{15}$ Lukachichnak elvileg elegendő számú csapata volt: 81 karhatalmi század és 37 géppuskás szakasz, sőt segítségül hívhatta az államrendőrséget és a vidéki karhatalmi alakulatokat is. ${ }^{16} \mathrm{~A}$ lőszerraktárak tele voltak, és komoly mozgójármű-állomány is az altábornagy rendelkezésére állt. Mégsem segített a jelentős katonai készültség, amiképpen Lukachich korábban sokszor bizonyított erélye sem. A megbízhatatlan menetszázadok elszállítását és a friss, vidéki karhatalom felhozatalát meghiúsította az akadozva múködő hadi bürokrácia és a gyorsan cselekvő Landler Jenő, a vasutas szakszervezet szocialista vezére, akinek hatékonyságát jelzi,

\footnotetext{
Szterényi József: Régi idôk emlékei. Politikai feljegyzések, Budapest, 1925. 163.; Windischgrätz Lajos: Küzdelmeim. Budapest, Szerzői kiadás, 1920. 117. Vö: Gömbös Gyula: Egy magyar vezérkari tiszt bíráló feljegyzései a forradalomról és ellenforradalomról. Budapest, 1920. 12.

8 Veres Péter: Számadás. Önéletrajz. Budapest, Püski, 1998. 123-124.

9 Ritoók Emma: Évek és emberek. Ritoók Emma visszaemlékezései I. 1914-1919. OSZK Kézirattár F473, I. 234. 105.

10 Siklós András: A Habsburg-birodalom felbomlása, 1918. Budapest, Kossuth, 1987. 87-88.

11 Buza Barna: Hogy veszett el Magyarország? Budapest, Schimkó Gyula, 1921. 7.

12 Balla Tibor: Katonai alakulatok karhatalmi bevetése Magyarországon az első világháború utolsó évében. A Hadtörténeti Múzeum Értesítôje, (2011), 12. 63-73.

13 Dálnoki-Kováts Jenő: A megélhetés drágulása a háború kitörése óta. Közgazdasági Szemle, (1921), 1. 266.

14 Barta Róbert: Magyarország az első világháborúban. In Kollega-Tarsoly István (szerk.): Magyarország a XX. században. I. k. Szekszárd, Babits, 1996. 33-35.

15 Lukachich Géza: Magyarország megcsonkitásának okai. Budapest, Nyukosz, é. n. [1932], 56-60.

16 Lukachich (é. n.) i. m. 64.
} 
hogy október 30-án éjjel leállíttatta a Budapestre érkező teljes vasúti forgalmat. ${ }^{17}$ A soroksári munkások felfegyverkeztek, gyakorlatilag kirabolva a fegyvergyárat október 29-én. ${ }^{18}$ A karhatalmi erők elhelyezkedése is a szervezetlenség és a lusta, nemtörődöm bürokrácia jeleit mutatta. A fáradt legénységi állomány az akkor külvárosinak számító Hungária körúti laktanyákban volt elszállásolva, s naponta kellett bevonulniuk a városba, míg a katonai hivatalnokok és az altisztek tágas belvárosi irodákban terpeszkedtek. A muszlim bosnyák katonáknak disznózsírral főztek (ők inkább éheztek), a többiek - a legénység magyar nyelvű többsége - romlott káposztát kaptak (ők meg zúgolódtak). Az egységek demoralizálódására jellemző, hogy a Lukachich kinevezésével egy időben alakult Katonatanács a parancsnoki rendelkezéseket megszerezte az altábornagy gépíró tisztjétől. A budapesti katonai rendőrséggel Lukachich semmire sem ment. Elkényelmesedett tisztjeik és altisztjeik többségükben üzletemberek voltak, akiknek sokszor kenőpénzen szerzett beosztásai a harctérről és a frontszolgálattól való távolmaradást és nem egy esetben talán a zavartalan kartellezést és lánckereskedelmet szolgálta. A kapkodás világos jele volt, hogy Lukachichtól elvárták, hogy rendet teremtsen, de azt is, hogy meggondolatlan akcióval ne akadályozza a lassan komédiába fulladó politikai kibontakozást. Fellépését emiatt az ellentmondás miatt nem kísérte - mert nem is kísérhette - szerencse. Az egyedüli összecsapás, a spontán tüntetésnek indult október 28-i úgynevezett „lánchídi csata" három halottja nem megfélemlítette a budapesti tüntetőket és a még mindig nem túl szervezett vezetőit, sokkal inkább felbátorította őket, míg a fegyveres erőket demoralizálta. (Egybehangzó visszaemlékezések szerint a tömeget Friedrich István tüzelte fel. A keresztény kurzus későbbi legitimista elindítója ekkor még Károlyi rendíthetetlen híve és elkötelezett szabadkőműves volt, s éppen a Habsburgok ellen lázított.) A felvonuló tömeg azt kiabálta a katonaságnak, hogy „ti is magyarok vagytok, ne bántsatok!". ${ }^{19}$ A katonák már nem is lőttek, csak a rendőrök - de már az ő soraik is bomlottak. Éjjel küldöttségük kereste fel Károlyit, és felajánlották neki szolgálataikat. ${ }^{20}$ „Számot vetettem politikai meggyőződésemmel, s rájöttem arra, hogy én voltaképpen szocialista vagyok" - nyilatkozta néhány héttel később a rendőri küldöttség egyik vezetője, akit érdemeiért főkapitány-helyettessé léptettek elő. ${ }^{21}$

Abudapesti rendőrség pálfordulása döntő jelentőségű volt, mivel ezzel az állami erőszakszervezetek utolsó eszköze esett ki a hatalom kezéből. Az erős kéz hívei egyébként is teljesen megbénultak. A törvénytisztelő Wekerle ügyvezető kormányának október 29-i utolsó ülésén elutasította a statárium kihirdetését. Az első „magyar október” úgy győzött, hogy a kormányhivatalok nagy része észre sem vette, nemhogy tenni tudott volna ellene. A Károlyi-palota szalonjaiból október 28-án az Astoria szállóba költöző

\footnotetext{
17 Lukachich (é. n.) i. m. 47.

1815 ezer Frommer pisztolyt és egymillió töltényt szereztek, a fegyverekre darabonként 60 töltény jutott. Jócsák Kálmán: Egy élet a harcok tüzében. Kézirat. PIL 867 f. j-109, 266.

19 Sándor László főkapitány jelentése a belügyminiszternek 1918. október 29-én PIL 686 f, 146 ô.e., 54.

20 Smoling Béla: Ötven év múltán. [1966], Kézirat a Fơvárosi Szabó Ervin Könyvtár Budapest Gyújteményében, Bq 323/206., 4-5.

21 Gellért Oszkár (szerk.): A diadalmas forradalom könyve. Budapest, Légrády, 1918. 156.
} 
Nemzeti Tanácshoz pártolt a rendőrség nagy része, október 30-án este a főposta is. A postáskisasszonyokat Hock János eskette fel a Nemzeti Tanácsra - az eskütételről Krúdy írt később lírai riportot -, a telefonközpontokban szintén a nők vették kezükbe a dolgokat. A milliomos irodalmi mecénás, Hatvany Lajos, aki a Pesti Napló tulajdonosaként és a Nemzeti Tanács tagjaként maga is az események közelébe került - úgy emlékezett, hogy a férfiak forradalmát a nők nyerték meg, akik a lekapcsolt telefonokkal tették lehetetlenné Lukachich intézkedéseit. ${ }^{22}$ (Nincs mit csodálkozni rajta: a háború éveiben nemcsak a szántóföldeken és a gépsorok mellett, de a pesti hivatalokban és a villamoskalauzok között is egyre több lett a nő, „Szakasz Zsuzsának” és „Átszálló Marcsinak” hívta őket a pesti nép.) ${ }^{23}$

\section{A Janus-arcú forradalom. A magyar vidék 1918 novemberében}

A történelmi Magyarország 1918. október 31-én összeomlott, győzött az őszirózsás forradalom. A „vértől és sártól boldogságos” pesti utcát egyszerre kerítette hatalmába a mámor és a felfordulás. A győztes őszirózsás forradalom estjén meggyilkolták a régi rend jelképét, Tisza Istvánt, s mikor a hír a belvárosba megérkezett, mindenki ujjongott. A forradalom vezére Károlyi Mihály jobb híján hagyta ott a közjogi küzdelmek járhatatlanná lett parlamenti tereit, s tért rá a forradalmi cselekvés ismeretlen ösvényeire. Tisza István meggyilkolása bizonyosan nem az ő megrendelése volt, de tehetetlen volt. ${ }^{24}$ Kormánya legszervezettebb ereje a Magyarországi Szociáldemokrata Párt képviselői az utcáról kerültek a miniszteri bársonyszékbe, s a választójogért folytatott 20 évnyi küzdelem után maguk is megosztottak voltak lehetséges-e választói felhatalmazás hiányában kormányzati felelősséget vállalni. Mivel a parlamenti padsorok helyett a pesti utca kövezetén tanulták a politizálást - a mindennapos fizikai erőszak pofonegyszerû világában -, nem csoda, ha az utca jogérzékét hozták a kormányzásba. ${ }^{25}$ Ezzel leginkább Garami Ernő, a legtekintélyesebb szociáldemokrata politikus volt tisztában. ${ }^{26} \mathrm{Az}$ ő álma a szocialista parlamenti jelenlét volt, évtizedek óta választójogot akart a munkásságnak, és nem forradalmat, demokratikus választásokat, nem kétes és forgandó szerencsét hozó utcai legitimációt. A Népszava kiváló szerkesztőjéből kiváló szakminiszter lett az ipari ügyeket is magában foglaló kereskedelmi tárca élén, csakhogy a forradalom ideje kevésbé a szakemberekre, mint inkább a politikai prófétákra

22 Hatvany Lajos: Egy hónap története. Esztendő, 1. (1918), 12. 124-125.

23 Ritoók (1914-1919) i. m. 125. Lásd még Szécsényi Mihály: Kalauznők tündöklése és bukása. Budapest, 34. (2011), 8. 31-33. A nők háborús munkavállalásáról lásd: Zalai Katalin: A nők „baljós” térfoglalása. A nők gazdasági mobilizációja az első világháború idején. In Egry Gábor- Kaba Eszter (szerk.): 1916 - a fordulat éve? Budapest, Napvilág, 2017. 229-264.

24 A Tisza gyilkossághoz: Hatos Pál: Felemás gyász - Tisza István meggyilkolása és a magyar közvélemény 1918-ban. Kommentár, (2018), 2. 12-23.

25 Bódy Zsombor: A hétköznapi élet története. Munkás visszaemlékezések a századforduló idejéből. In Bódy Zsombor - Mátay Mónika - Tóth Árpád (szerk.): A mesterségek iskolája. Tanulmányok Bácskai Vera 70. születésnapjára. Budapest, Osiris, 2000. 285-286.

26 Garami Ernő: Forrongó Magyarország. Emlékezések és tanulságok. Lipcse-Bécs, Pegazus, 1922. 105. 
bizonyult kedvezőnek. A szociáldemokraták másik kulcsembere - a Garamival szemben Károlyi barátságát sokkal inkább élvező -, Kunfi Zsigmond sem volt született próféta, de ôt az idők lázas hangulata sokkal jobban magával ragadta. Számára természetes volt, hogy „nem talált egyetlen forradalmár jogérzete sem kivetnivalót azon, hogy a győtes forradalom elpusztította legkonokabb ellenfelét, Tisza Istvánt” ${ }^{27}$ Akkor úgy tűnt, nemcsak a pesti utca szocialista prófétái, hanem maga a „nép” is így gondolta, nemcsak Budapesten, hanem a bihari pusztákon is. Tisza István geszti temetésén egy ember se vette le a kalapját és falubelijei azt sem engedték, hogy a templom harangjai szóljanak. ${ }^{28}$ Végre vége lett az öldöklésnek - de ami utána következett abban sem volt köszönet. Az elhúzódó háború dicstelen befejezésével egyszerre kiderült, hogy nem a békéhez füzött felfütött várakozások fognak beteljesülni arról, hogy a világ rendje helyreáll, s ami eltört, összeforr. Hanem hogy a nyomor és szenvedés csak most kezdődik igazán, amikor a társadalom többsége az erőinek végképp a végére ért. ${ }^{29} \mathrm{~A}$ háborút nem csak pusztító influenzajárvány követte, gróftól a cselédig, gyárostól a napszámosig 120 ezer ember esett áldozatául a halálosztó demokratikus vírusnak, amely ellen nem használt sem a hatósági karantén, sem a csodadoktorok újságokban hirdetett csodaszerei. Hanem kis helyi háborúk százai is: vezér és eszme nélküli parasztforradalom szerte az országban. A leszerelő katonavonatok a dühöt terítették szét szerte az országban, egyik napról a másikra összeomlott a közigazgatás, a jog- és vagyonbiztonság, a vidék a becslések szerint 1000 halottal fizetett a hazatérő katonák és a háború nyomorúságaiban magára hagyott „hadiasszonyok” felfordulásának lecsendesítéséért, az államháztartás 8 milliárd korona többletkiadással, a gazdaság pedig a termelés drámai csökkenésével. Az a fájdalmas rádöbbenés pedig, hogy a független Magyarország küszöbéről a történelmi Magyarország sírgödrébe lehet csak lépni, kevesebb, mint öt hónap alatt felemésztette demokratikus reformkísérlet minden hitelét. ${ }^{30}$

A forradalom tehát nem állt meg a főváros határainál. 1918 novemberének első két hetében a 20. század legnagyobb méretû spontán paraszti forradalma bontakozott ki Magyarországon. Az egész országra kiterjedő mozgalmak a töredékesen fennmaradt ügyészi jelentések szerint félezernél több települést érintettek, és óvatos becslések szerint is 100 ezren felüli résztvevőt mozgathattak meg. ${ }^{31}$ A nép forradalma semmiképpen sem volt „magyar forradalom”, a verbálisan artikulálatlan erőszak legtöbbször csak kísérőjelensége volt az elitek nyelvén végeredményben értelmezhetetlen, formátlan dühkitörésnek, amely viszont nem tudott vagy nem akart mit kezdeni a politikailag iskolázott fülnek ismerős frázisokkal. ${ }^{32}$ „Hiába vártuk őket

\footnotetext{
Kunfi Zsigmond: Különvélemény a Tisza-pörben. Világosság, (1920), augusztus 18. 187.

Zelenski Róbert: Emlékeim. Budapest, Pallas, 1928. 754.

Kóbor Tamás: A bolsevizmusról a bolsevizmus alatt. Budapest, Franklin, 1919. 22-23.

Apáthy István: Erdély az összeomlás után. Új Magyar Szemle, (1920), 2-3. 149.

31 Schönwald Pál: A magyarországi 1918-1919-es polgári demokratikus forradalom állam-és jogtörténeti kérdései. Budapest, Akadémiai Kiadó, 1969. 38.

32 Lásd a kérdéskörről a tanulmányommal egy időben készített, igaz csak részben azonos forrásbázison, de sokszor hasonló következtetésekkel dolgozó kiváló társadalomtörténeti tanulmányt: Csíki Tamás: A parasztság „forradalma” 1918-ban. In Bódy Zsombor (szerk.): Háborúból békébe: a magyar társadalom 1918 után. Budapest, MTA Bölcsészettudományi Kutatóközpont Történettudományi Intézet, 2018. 129-150.
} 
meleg étellel, kávéval; hiába kötöttük lelkükre a haza védelmét; mindenki sietett tűzhelyéhez haza" - idézte fel a frontról hazatérő székely parasztkatonák közömbösségét Apáthy István, amikor Erdély elvesztésének okait boncolgatta. Az első napokban nem a szeparatista törekvések vezették a nemzetiségi vidékek megmozdulásait sem. Erdély belső vidékein a román parasztok csóvát vetettek az udvarházakra. Ezek többségének valóban magyar volt a tulajdonosa, mégsem a dákoromán reneszánsz perspektívája vezette a gyújtogatókat, hanem az úrgyülölet. Bethlen István mezősámsondi kastélyát ugyanúgy megtámadták, mint a román nacionalista vezér, Mihályi Tivadar (Theodor Mihali) nagyilondai birtokát, amikor az a közelgő román hadsereg intézkedéseiről akarta őket tájékoztatni. A nemzeti felszabadulás evangéliumát kőzáporral fogadó több ezer román paraszt sortüzet kapott viszonzásként a román nemzeti párt vezérétől. 1918. december 1-jén éjjel, a Kolozsvár felé haladó különvonaton egy magyar vasutas és egy román parasztkatona beszélgetett. Ez utóbbi a nevezetes gyulafehérvári gyúlésről jött haza, ahol a román nemzetiségi vezérek százezer ember előtt deklarálták Erdély egyesülését Romániával. „Mit határoztak Gyulafehérváron?” - kérdezte a magyar, mire a román katona azt felelte: „Ezentúl nem lesznek urak, csak szegény emberek, és minden szegény ember egyenlő lesz.” „Hát ez bizony jó lesz" - hagyta rá a magyar. ${ }^{33}$ Nagy-Románia létrejöttének ez volt a népi percepciója 1918 kavargó őszén.

A demokratikus átalakulás programjának szintén sajátos volt a paraszti recepciója. Az őszirózsás Károlyi Mihálynak keserű iróniával kellett tudomásul vennie, hogy parádi kastélyát a heves megyei szegényparasztság már a legelső napokban kifosztotta, éppúgy, mint reakciós apósának, Andrássy Gyulának tiszadobi kastélyát, és ugyanezt tették a Károlyi médiahátországát megteremtő liberális iparbáró, Hatvany Lajos báró hatvani kastélyával és cukorgyárával is. Az úrgyülölet váratlanul lobbant fel. Az apolitikus paraszti ellenállás, amelynek a háború utolsó éveiben a terményelrejtés, a katonaszökevények rejtegetése, az adók alól való kibújás volt a fegyverzete, szemmel láthatóan lázas szakaszába lépett. Ôsi, de legalábbis évszázados mintákat idézett a gyújtogatás, a rablás, a talált pénz széjjelszórása vagy az úri kúriák értékes bútorainak vandál összetörése. Ha nem akadt kastély vagy árukkal rakott vasútállomás a környéken, akkor az urak és az állam helyett a szomszéd lett az ellenség. Sok helyütt a forradalom abból állt, hogy a hazatért katonák és/vagy a helyi szegénység lerohanta a szomszéd falu vagyonosabb gazdáit. Mindebben vajmi kevés volt a tudatosság. „A forrongás fó okául a háború okozta anyagi nyomorúságot állította oda a nép. Nincs árpa, bab, burgonya és tengeri" - írta a kalocsai főszolgabíró, akiben - ritka eset - megbízott a nép, mert a háborúból rokkantként tért haza. ${ }^{34}$ Alkalom szülte tolvajok is akadtak bőven, akik lovas szekérrel mentek fosztogatni, s olyan népmesei helyzet is előfordult, hogy egy-egy gazdag parasztgazda visszatérve a fosztogatásból saját házát és gazdaságát szintén kifosztva találta. A „has vészjósló forradalma”

\footnotetext{
MNL MOL K40 1918 IX 677.

34 Romsics Ignác (szerk.): Dokumentumok az 1918/19-es forradalmak Duna-Tisza közi történetéhez. Kecskemét, Bács-Kiskun Megyei Levéltár, 1976. 202.
} 
több esetben „a mindenki háborúja mindenki ellen” ősállapotába vetette vissza a vidéket, amiképpen ezt számos fennmaradt dokumentum igazolja. A felfordulás a paraszti mikrotársadalmon belül is alkalmat adott a konfliktusok erőszakkal való lerendezéséhez. Szótlan béresgyerekek, cigányok, a faluba befajzott napszámosok, hallgatag kocsmatöltelékek, akiket a kikapós feleségük haragított össze az élettel, most egyszerre fellázadtak a nagygazdák ellen, és meglincselték a tanító fiából lett őrmestert, aki a fronton kínozta őket, ahogy ezt Németh László első regénye az Akasztófavirág megörökítette. Még inkább kiélesedett a város és falu, termelő és fogyasztó, földművelő és munkás háborúban kifejlődött ellentéte. Nem volt egyedi eset, hogy a Szeged melletti Nagyszénás lefoglalta az uradalom Szegedre szállított tejtermelését, „mert másként a rendet a községben fenntartani nem tudná”. ${ }^{35}$ Város és vidék háborújának csúcsjelenete volt Kaposvár kifosztása 1918. december 11-én éjjel. Somogy megye székhelyére egy olyan banda támadt, amelyben a többséget a közelebbi és távolabbi környék fiatal parasztkatonái alkották, de az éj folyamán hozzájuk csapódott a város félvilágának társadalma is a Vár utcai bordélyház kéjhölgyein át a külvárosok cigányságáig, sőt a módosabb környékbeli gazdák sem akarták elmulasztani a kínálkozó alkalmat. Körülbelül 500 fő részvételével egész éjjel tartott a szabad rablás. A városi rendőrkapitány és a megyei alispán kétségbeesetten lapultak, amíg a felgyújtott üzletek fényénél a cselédkorzón vidáman hullámzottak a hetesével-nyolcasával egymásba karoló, daloló lányok. Legalábbis így írta le a szemtanú jelmezét magára öltött Illyés Gyula a Boccaccio Dekameronjába illő véres forgatagot. ${ }^{36}$ Regényes leírása nagyjából-egészében helytállóan adja vissza az atmoszférát. A rablott holmival megrakott lovas szánok csilingelése egybefolyt a puskák ropogásával és a kurjongatással. Reggelre a füstös, korom- és lőporszagú belváros valóságos háborús csatatér képét mutatta. A kifosztott és megfélemlített kaposvári polgárság - mintegy fél tucat halott maradt az ádventi véres farsang nyomán - a Baranyát ekkor már megszálló szerb hadsereg behívásáért könyörgött. Ôk jöttek is volna szíves-örömest, de rendet végül a Budapestről leküldött géppuskás tengerészkülönítmény tett. Hasonló események történtek Nyíregyházán és Szolnokon is.

A ma is kevéssé ismert paraszt- és katonaforradalomnak széles földrajzi kiterjedése ellenére sem volt semmilyen szervezett, még kevésbé intézményesült jellege. Nem voltak vezérei, legfeljebb helyi hangadói, s nem volt ideológiája, ha csak nem a „leszámolunk mindenkivel” jelszava. S mivel nem hierarchikusan épült föl, nem volt és nem lehetett „élcsapata” sem: a helyi paraszti megmozdulások csupán egymástól elszigetelt, forrongó enklávékat alkothattak, amelyek szó szerint „magukban füstölögtek." A győzelem minden reménye nélkül. Talán ezért sem akadt később sem krónikása, hiába próbálták többen is vörösre festeni a paraszti anarchia sokszínú és ellentmondásos jelenségvilágát az 1950-60-as évek kommunista diktatúrájában. Az orosz bolsevizmus hatása kétségtelen volt ugyan, ám mindaz, ami történt,

Sinkovics Pál, a Nagyszénási Nemzeti Tanács elnökének válasza a Szegedi Nemzeti Tanács panaszára. 1918. november 22. MNL MOL Nemzeti Tanács iratai 1918-1919, K440 X1511 6996. doboz (mikrofilmmásolat).

36 Illyés Gyula: Kora tavasz. Budapest, Szépirodalmi Könyvkiadó, [1941], 1972. 131. 
egyáltalán nem valamiféle proletáröntudat megnyilvánulása volt, csupán az „ezután már az urak fognak dolgozni és köszönni nekünk” dühkitörése. ${ }^{37}$ A bázisdemokrácia és a törvényszegés sajátos ötvözetét képezték az országszerte létrejött nemzeti és katonatanácsok is. Létrejöttük spontán volt, és rendszerint a helyi község lakosságának jelentős részvételével alakultak meg - volt ahol 100 fős testületek jöttek létre -, bár szinte sohasem egyesítették a helyi társadalom teljességét. A tömeg, a tömegesség tapasztalata olyan legitimációt adott, amely könnyen túllépett az írott normákon és íratlan szokásokon. A helyi nemzeti tanácsok minden további nélkül adót vetettek ki a gazdagokra (hogy ki számított gazdagnak, az természetesen faluról falura váltakozott), árut foglaltak le önkényesen (főként ott, ahol volt vasútállomás, raktár, gyártelep), vagy egyszerűen elrekvirálták a nagyobb gazdaságok vetőmagkészleteit, a hizlalt disznókat, marhát stb., és szétosztották a faluvég szegénysége között. Több helyütt egyszerűen elmozdították a néppel szemben tanúsított durva és goromba bánásmódjuk miatt mindazokat, akiket méltatlannak ítéltek a hivatalviselésre. Demokratikus mámor és diszkrimináció kéz a kézben járt. Az abaúj-tornai Jósvafőn úgy határoztak a hazatért katonák, hogy csak hadviseltek lehetnek tanácstagok, ugyanakkor az egyenlőség nevében egy katonaságtól leszerelt cigányt is beválasztottak a helyi nemzeti tanácsba. ${ }^{38}$ Volt olyan település, ahol az „összes urakat” megöléssel fenyegették, persze az orvos és a gyógyszerész kivételével, mert rájuk akkor is szükség van, ha nincs többé király és alkotmány. De ha megértették az idők szavát, akkor megbecsülést kaptak akár a „fekete kabátosok”, azaz a papok is. Csepelen például a Nemzeti Tanács a hitoktató káplánnak heti 60 korona fizetéskiegészítést szavazott meg a hittanórák után. „Vörös Csepel” így gondoskodott a papi proletariátusról. Másutt is előfordult, hogy egy lelkész vagy akár egy „magát jól viselő” jegyző lett a nemzeti tanács elnöke, ahol viszont a tekintélyek teljesen lejáratódtak, ott vadorzók és kétes egzisztenciák lettek egy időre a falvak vezetői. A Somogy megyei Istvándiban a Nemzeti Tanács elnöke rögtön kijelentette, hogy „a törvények mind semmisek, a főispán, alispán, csendőrörs nem létezik többet”, és a népuralom jogcímén néhány falubeli hangadó társával kezébe kerítette a hatalmat, maga számára szedte be az adókat, és értékesítette a községi vagyontárgyakat. Az anyakönyvvezetés és a közigazgatás írásbeli tevékenysége hónapokra megszűnt a faluban. ${ }^{39}$

A nemzetiségi vidékeken az urak elleni lázadáshoz könnyen társult magyargyűlölet, hiszen a falubeli birtokosok, a kastélyok lakói többnyire magyarok voltak, de ez is csak kísérőszólam volt a béke féktelen fiestával való megünnepléséhez. Országszerte a jegyzői kar legkevesebb egyharmadát elzavarták szolgálati helyéről, Erdély egyes román vidékein akár $90 \%$-uk is elmenekült a népharag elől. Tucatnyi jegyző életével fizetett azért, amiért korábban a szabadságolások, felmentések, hadisegélyek

37 Takács Mihály: A forradalom és a református egyház. Sárospataki Református Lapok, (1919), 1. 3.

38 Hajdu Tibor: Katonák, hivatásos tisztek szerepe a magyar és az orosz forradalmakban (1917-1921). Történelmi Szemle, (2009), 4. 530.

39 A Barcsi Határszéli Államrendőrség kirendeltségvezetőjének jelentése az Istvándi község Nemzeti Tanácsának tagjai ellen lefolytatott bűnvádi eljárásról 1919. január 20-án, MNL SML Főispáni iratok IV. 401. a. 547/1919. 
kieszközléséért anyagi javakat és/vagy szerelmet zsaroltak a katonák hozzátartozóitól. Volt, ahol földbe ásták a gyűlölt elöljárót, s úgy verték agyon, máshol kikötözték a közlegelőre, mert a háború alatt az éhező asszonyokat azzal utasította el, ha nincs kenyerük, menjenek ki a mezőre füvet legelni. ${ }^{40}$ Sok helyütt a papok és lelkészek sem jártak jobban. Ők is „hosszúnadrágos” embereknek számítottak: vagy anyagi visszaéléseket róttak a terhükre (miért eskettek és temettek olyan drágán), vagy csupán azt, hogy a rendszer kedvezményezettjei voltak. November lázas napjaiban öltek zsidó kántort a békési Tótkomlóson, katolikus papot az udvarhelyszéki Zetelakán, román pópát a szilágysági Ballaházán. ${ }^{41}$ A Somogy megyei Igal papja „fegyveres szerenádot” kapott, csak hogy tudja, „más világ van, mint a háború előtt” ${ }^{42}$ A háromszéki Kézdiszentléleken viszont már egyenesen így beszéltek: „Most megvan a béke, nincs szükség az Istenre, le kell rombolni a templomot." ${ }^{33}$ De csak a toronyra eresztettek néhány lövést, aztán lehiggadtak. Máshol viszont nagyon is sürgősen szükség lett az Istenre. Pest megye több településén a hazatért katonák fegyverrel kényszerítették a plébánost, hogy adja őket össze a menyasszonyukkal. A pisztolycsővel kikényszerített egyházi áldásra azért volt szükség, mert a lelkész a polgári házasság megkötése nélkül nem akarta az egyházi szertartást elvégezni, különben súlyos börtönbüntetést kockáztatott volna. A polgári anyakönyvvezetésre viszont azért nem kerülhetett sor, mert a jegyzőt ugyanezek a katonák már elüldözték a községből. ${ }^{44}$

Mások bűneiért fizetett a falvak zsidó kispolgársága is. „Megint a zsidók voltak azok, akiken a régi idők porát kiporolták" - írták keserú humorral az érintettek. ${ }^{45}$ A számos esetben előforduló brutális antiszemita és egyházellenes kilengéseknek hasonló volt az indítéka: a nép a zsidókat is a falvak úri társadalmának tagjaiként tartotta számon. „A jegyzőket és a felmentett zsidókat nem védjük meg, mert megérdemlik a sorsukat" - üzenték meg Debrecenből az újlétai jegyző segélykérésére a helyi Nemzeti Tanácsból. ${ }^{46}$ Budapestre, a kormánynak ugyanakkor azt táviratozták: „A vidék népe félreértve a forradalmat, pogromot rendez urak és zsidók ellen." ${ }^{\text {"7 }}$

40 Hajdu Tibor: Az 1918-as magyarországi polgári demokratikus forradalom. Budapest, Kossuth, 1968. 98.

41 Tengely Adrienn: Magyar egyházak a forradalom korában. Eger, Líceum, 2011. 20. Tengely tévesen rabbit ír, pedig forrása, az Egyenlőség egyértelmúen közli, hogy a meggyilkolt áldozat, Glück Mór a helybeli hitközség kántora volt. Lásd: A forradalom szenvedései. Egyenlőség, 37. (1918), november 23. 8.

42 Andrássy Antal: A polgári forradalomtól a szocialista forradalomig (1918. ősze). In Kanyar József (szerk.): Somogy megye múltjából - Levéltári évkönyv 19. Kaposvár, Somogy Megyei Levéltár, 1988. 278.

43 Tengely (2011) i. m. 24.

44 Persián Ádám kormánybiztos visszaemlékezései PIL 704. f. 12. őe. 16.

45 Ballagi Ernő: A forradalom és a zsidóság. Egyenlőség, 37. (1918), 47. 1.

46 Háry Ferenc újlétai jegyző levele a hadügyminiszterhez 1918. november 8-án. HL Polgári demokratikus forradalom iratai, I.29. 12/1. 294.

47 MNL HBML IV. B. 917 Hajdú vármegyei nemzeti tanács iratai 1. dob. 38/1918. A debreceni nemzeti tanács távirata a budapesti nemzeti tanácsnak, 1918. november 2 . 


\section{„Soha többé katonát nem akarok látni!” A katonák hazatérése és a leszerelés anarchiája}

A rend összeomlásához, a vidék forradalmához három dolog kellett. Az összeomlás váratlan és minden várakozást messze meghaladó mértéke, az új hatalom kapkodásai és mindenekelőtt a hazatérő katonák, akik a háború brutális mintáit elsajátítva érkeztek vissza otthonaikba. A forradalom október 31-ei győzelmének hírére a hadsereg országban állomásozó pótkeretei felbomlottak, és november 1-jén és 2-án a tisztek arra ébredtek, hogy nincs kinek parancsolniuk, egyedül maradtak a laktanyákban. A legénységi állomány október 29. és november 6. között, tehát egy hét alatt 50-90\%-kal csökkent. ${ }^{48}$ Volt, ahol még ennél is jobban. A nagyszebeni helyőrségi kórházból nemcsak az összes ott ápolt - jórészt nemi beteg - katona szökött meg, hanem a teljes ápoló személyzet is. Csak a halottak maradtak. A halottas kocsi bakján a kórház főorvos-parancsnoka ült, a koporsóvivők a különböző felekezetek lelkészei voltak. ${ }^{49}$ Ugyanaznap este Kolozsváron az erdélyi magyar fegyveres erők főparancsnokának nem volt tíz embere sem, akivel rendelkezhetett volna. ${ }^{50}$ Kolozsvár még mindig jobban állt, mint Budapest. November 1-jén a fővárosi kaszárnyákat végiglátogató Linder Béla összesen hat közlegényt talált. ${ }^{51}$ Batthyány Tivadar belügyminiszter november 2-án a csendőri egységeknek már csak a kész helyzet tudomásulvételét tudta javasolni: „Katonák nagyobb számban hagyják el a helyőrséget, és lakóhelyeikre önként távoznak. Felhívom alosztályait, hogy a hazaözönlő katonasággal szemben semmiféle megtorló intézkedést ne tegyen." ${ }^{2}$ Sőt Batthyány maga szólította fel a karhatalmi erőket a hatalmukat szimbolizáló distinkciók - sapkarózsa, tiszti rendjelek stb. - eltávolítására. Azaz a szimbolikus fegyverletételre. A csendőrség, ha nem is oszlott fel teljesen, a következő hónapokban bénán vegetált, és a korábban rettegett kakastollasok tétlenül húzódtak meg egyik-másik uradalomban. A „népkormányt” úgyis lehetett érteni: az állam eltűnt, a hatalmát megjelenítő hierarchiával és szimbólumokkal egyetemben. A monarchikus rendszer összeroskadásáról szóló hírek úgy csapódtak le, hogy „ha nincs király, nincs törvény és nincs adó”. A hazatérő katonasággal a paraszti társadalom megszokott tereinek egy jelentôs része ideiglenesen mintegy levált az államról, kikerült annak erőszak-monopóliuma és hatalmi ellenőrzése alól. Az államés katonai hatalmat jelképező szimbólumok érvénytelenné válásával a társadalmi feszültségeket kontroll alatt tartó fékek is elengedtek. A trencséni kaszárnyából eltávozott honvédek másnap már a környező szlovák parasztsággal együtt fosztogattak a környéken. „A vidék elvadult. Elvadult vagy felszabadult? Egy hét alatt ezer esztendő

\footnotetext{
48 Habár az adat a magyar tüzérség felügyelőjének jelentéséből származik, bátran tekinthetjük az összes fegyvernem és az egész magyar haderő tekintetében reprezentatívnak. HL I/29-8. 133.

49 A forradalom lezajlása Nagyszebenben, katonatanácsok 1918. október 30-tól 1918. november 30-ig. A nagyszebeni hadapródiskola ismeretlen nevú tisztjének naplójegyzete. HIL TGY 255. 2.821. 7-8.

50 Apáthy (1920) i. m. 155.

51 Buza Barna vallomása a népbiztosok perében 1920. augusztus 2-án, BFL. VII. 5.c 1920-6274. 162. doboz, XLVIII doszszié, 3075-3076.

52 Szemere Vera: Az agrárkérdés 1918-1919-ben. Budapest, Kossuth, 1962. 226.
} 
fejlődését érzékeltette, játszotta el visszafelé, ahogy a szervezett állam kötelékeiből kibújt s visszavedlett - ördög tudja, mivé is vedlett vissza" - kereste a szavakat a jellemzésre Illyés Gyula. ${ }^{53}$

Természetesen lehet vitatkozni azon, hogy az atavisztikus erőszak vagy az ölni tudás háborúban elsajátított rutinja vezetett-e az állam időleges összecsuklásához. Mielőtt azonban az egész felfordulást a Károlyi-kormány nyakába varrnánk, érdemes felidézni, hogy a harcterekről megindult katonaság első hullámai már november 1-jét megelőzően Magyarországon voltak. Rendetlenül és rabolva. A rendőrség a legtöbb helyen évek óta gyenge volt, még békebeli feladatait sem tudta ellátni. A több mint 10 ezer lakosú Sepsiszentgyörgyön 1918 tavaszán a rendőrség legénységi állománya összesen három főből állt. Somogy megyében a főispán egy fütetlen kunyhóban nyomorgó csendőrőrs sorsának javításáért instanciázott a Belügyminisztériumban. ${ }^{54}$ A gyeplőt nem Batthyány és társai dobták a lovak közé. A Wekerle-kormány nem tett érdemi intézkedéseket a milliós hadsereg fogadására, hanem mintegy megdermedve várta az elkerülhetetlent. Így amikor a front megindult hazafelé, csak a rettegés maradt. A tehetetlenséget fejezték ki az olyan pótcselekvések, mint az Erdély keleti szélén lévő Beszterce-Naszód vármegye törvényhatósági bizottságának 1918. október 30-án - vagyis a forradalom kitörése előtt! - hozott határozata, amelyben szigorú antialkoholista szellemű törvény meghozatalát kívánták a kormánytól. A körülményeskedő indoklás szerint „a vármegye közönsége aggódva gondol a közeledő leszerelés alkalmával hazatérő katonáink és családtagjaik az alkoholnak minden bizonnyal bekövetkező túlságos élvezete következtében fenyegető egészségi, anyagi és erkölcsi romlására, amitől végeredményben még a közrend, béke és közbiztonság megromlását is félti". ${ }^{55}$ Mindenesetre sok helyen nem diadalkapuval várták a visszatérőket, még ha a kormány első intézkedései között rendelkezett is a katonák ünnepélyes fogadásáról. És persze az alkoholtilalomról: „Ne igyunk alkoholt!” - hirdették öles betűkkel vidéken és városban egyaránt a plakátok, a pálinkaméréseket bezárták, a vendéglőkben megtiltották az alkohol felszolgálását. Az otthon maradottak részéről félelem, idegenkedés és szánalom keveredett a hősök viszontlátásában: „Az olasz frontról özönlenek haza a katonák; mikor a villamoson Pestre jövök, minden alkalommal látom, hogy a vasúti átjárónál egy végtelen hosszú vonat nyúlik lassan tovább, vánszorog Pest felé, hozva a testi és lelki betegségeket. Vonatok, kitört ablakokkal, rongyos üléseikkel, melyekről lehúzták a bőrt és a posztót, telve-telve, a lépcsőkön állnak, lógnak, kapaszkodnak, az ütközőkön lovagolnak, a tetőn ülnek, az ablakok telve fejekkel, szinte lógnak ki a fejek, mintha nem tartoznék hozzájuk test sem. Döcögő, fekete füstöt okádó vonatok. Hová megy ez az irtóztató sok nép? Állati ez, ahogy innen kívülről látszik, de nem hangyákra vagy méhekre emlékeztet, hanem az embereknek valami állati eltorzult irányítására Pest felé és onnan tovább. Hová?” - fejezte ki Ritoók Emma

\footnotetext{
53 Illyés (1972) i. m. 99.

54 Nagy Szabolcs: Egy székely város közállapotai az első világháború végén. A sepsiszentgyörgyi rendőrkapitány 1918. áprilisi felirata a megyei alispánnak. Acta Siculica, (2011), 353.

55 MNL MOL K 440 A Magyar Nemzeti Tanács iratai 1918-1919. X1511 6997. doboz (mikrofilmmásolat).
} 
az itthoniak ambivalens érzéseit és az elbizonytalanodott polgári társadalom tanácstalan passzivitását. ${ }^{56}$ A felbolydult Keleti pályaudvart felkereső fiatal Márai Sándor viszont meggyőződéses pacifistaként tudósított a háború fináléjáról: „A keramit-padlón vastagon áll a sár. Egy baka bejön, tépett ruhában, födetlen fejjel. Lát a padlón egy embernyi helyet. Lefekszik: bele a sárba, csapzott hajú fejét belefekteti, már alszik. Ez a tökéletes elfáradás, ez a minden mindegy, ez a végső odaengedés: ez az utolsó gesztusa a háborúnak, ez a csöndes, elbékülő, elengedő fináléja a szenvedéseknek."57

A fegyverletételi parancsot november 1-jén, az azonnali leszerelésról szóló rendeletet néhány nappal később Linder Béla hadügyminiszter adta ki, de a pánikban született végzetes hadparancs nem elindította, legfeljebb felgyorsította az elkerülhetetlent: a megvert és kifáradt, hazafelé tartó hadsereg felbomlását.

A fegyelem ugyanis többé nem parancs kérdése, a legénység pedig nem „puskalétszám”, hanem önállóságra ébredt, érző és vérző valóság volt. „Nem kell, komám, többé az Atyaúristennek sem tisztelegni” - mondták a bakák egymásnak és az elképedt tiszteknek mindenütt. ${ }^{58} \mathrm{~A}$ kaszárnyák nem parancsra ürültek ki az egész országban Trencséntől Kolozsvárig és Soprontól Nyíregyházáig, hanem azért, mert a szolgálati hierarchia összeomlott, a nyilvánosság fegyelmezett terei pedig a kontroll alól kicsúszott erőszak labirintusává változtak. Lindert tehát kétségtelen pacifizmusán kívül az is vezette, hogy a katonák lehetőleg fegyver nélkül érkezzenek haza, nehogy itthon még nagyobb gondot okozzanak. A bűnbakkereső emlékezet elfeledteti, hogy Linder parancsa az akkori polgári közvéleményt fejezte ki. Mindazokét, akiknek még volt vesztenivalójuk, s akik nem is titkolták csalódásukat, hogy a kedves parasztbakák micsoda rossz fiúkként jöttek haza. „Akiket ölelő karokkal vártunk, akiktől a békésségünket és biztonságunkat reménylettük, azok űzik el szemeinkről az álmot, a lelkünkből a bátorságot, és a jövendőhöz való jó reménységünket is megszégyenítik."59 A „soha többé katonát nem akarok látni” kijelentése részben erre a félelemre adott válaszkísérlet is volt, legalább annyira, mint pacifista meggyőződés. ${ }^{60}$ Akinek volt még valamije 1918 őszén, az riadtan és dermedve nézte a katonák hazajövetelét, és mindent megadott volna azért, hogy a katonák mielőbb fegyver nélkül legyenek.

A zsúfolt vonatokon és országutakon érkező magyar alakulatok legfeljebb kisebb kötelékek méretéig őrizték meg szervezettségüket; a régi szigorú fegyelem nem volt már sehol, a tisztek már nem parancsoltak, legfeljebb kérleltek. „Nincs már tiszt, nincs feljebbvaló" - ordibálták a marhavagonok túlzsúfolt kupéiban egymás ölében kuporgó, megfélemlített és fegyvertelen tisztekre a megvadult közkatonák. A hadsereg felbomlásának mértékét jól jelzi az az adat, hogy november 7. és 30. között zárt csapatszállítmányban 360 ezer katona érkezett vissza a harcterekről, miközben ugyanebben

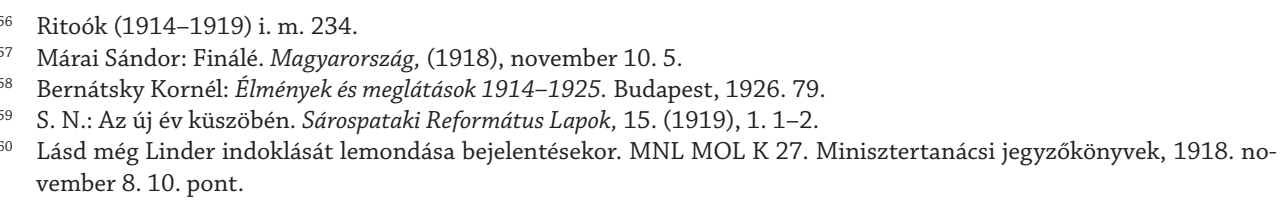


az időszakban a budapesti pályaudvarokon több mint 1 millió hazatérő katona ment keresztül. Amint a túlzsúfolt vonatok meghozták a katonákat, az anarchia lassan eluralkodott az országon. Szinte látni lehetett, ahogy a vonatok óráról órára egyre több haragot, dühöt és fosztogatási kedvet hoznak az országba. Az éhesen hazatérő katonákat éhező asszonyok várták. Dühösen, szegénységük szégyenében. A fegyverrel érkező katonák segítségével sokszor ezek a „hadiasszonyok” álltak a fosztogatások és rablások élére. ${ }^{61} \mathrm{Az}$ átmenet gyakran túlszínezett brutalitása korántsem csak férfiak ügye volt, vagy a „férfiasság” háborúban megrendült válsága. Az erdélyi Csucsán a zendülés azzal kezdődött, hogy asszonyok és gyermekek agyonverték az iparvállalat zsidó kantinosát, borát, pálinkáját kicsi és nagy egyaránt itta. A délvidéki Tiszakálmánfalva állomásán egy hosszú, petróleum- és benzintartályokkal megrakott vonat vesztegelt. A környéken fosztogató csőcselék megtámadta az állomást, kiütötte a tartályok oldalát, és vödrökkel mérte ki a petróleumot és a benzint. Az egyik fosztogató cigarettára gyújtott, és az eldobott égő gyufa egy benzinnel teli vödörbe esett, amely azonnal fölrobbant. A túz átterjedt a vonatra, és a tartályok is sorban felrobbantak. A robbanás ereje a levegőbe röpítette a fosztogatókat, akik összeégett, szétzúzott testtel zuhantak vissza a földre. A tűzeső lángba borította a rablásban részt vevő asszonyok és leányok ruháját is. A katasztrófának 60 - főként női - halottja és több száz sebesültje lett. Nem csoda, ha az utazásról nemcsak Budapesten, de vidéken is igyekezték lebeszélni a polgárokat. Miskolcon a frissen megalakult Nemzeti Tanács azt hirdette öles betúkkel, hogy „ne utazzunk”, azaz ameddig a katonaság hazatérése be nem fejeződik, a polgári utazóközönség a saját érdekében inkább tartózkodjon a vonatra szállástól. ${ }^{2}$ Ugyanaznap a városban élő szülőket is figyelmeztette, hogy 14 éven aluli gyermekeiket tartsák otthon - no, nem a gyerekek biztonságáért aggódva, hanem azért, mert a gyerekek által okozott rendzavarásért és rablásokért a szülőket fogják felelősségre vonni. (A háború alatt a fiatalkorú bűnelkövetők száma megháromszorozódott.)

„A népben meggyőződéssé vált, hogy nincs törvény” - állapították meg a forradalom jogászai a közönséges bűncselekményekkel kapcsolatban, de azon vitatkoztak, az amnesztiatörvény inkább árt vagy használ az indulatok leszerelésére. ${ }^{63}$ Végül mégis rángatták a gépfegyverekkel, szuronyokkal és statáriummal fékezték meg az indulatokat. A Krasssó-Szörény megyei Facsádon géppuskás repülőgép teremtett rendet. 30 méter magasból leadott lövéseinek nyomán 104 halott maradt a földön. Temesvárról más helységekbe is küldtek katonai alakulatokat, amelyeknek részvételével több lázadó faluban „községenként 12-20 főt végeztek ki”. Többre már csak azért sem maradt idő, mert november közepére a szerbek elfoglalták a Bánátot, a tűzparancsot

\footnotetext{
61 „A Miskolc közeli zavargásban szinte az egész falu népe részt vett, főleg az asszonyok uszították a férfiakat a rablásra, fosztogatásra.” MNL MOL K46 PTI 605f. TAGYOB 10. doboz. II/ 19 őe.

62 A Magyar Nemzeti Tanács miskolci végrehajtó bizottságának felhívása 1918. november 1-jén. MNL MOL K46 PTI 605f. TAGYOB 8. doboz. II/9a dosszié.

63 Jegyzőkönyv a Nemzeti Tanács Igazságügyi Szaktanácsának 1919. december 19-ei üléséről. MOL K440 PTI $607.30 ̈ e$, 20-30.
} 
elrendelő Bartha Albertet pedig Károlyi Mihály hadügyminiszterré nevezte ki Linder utódjául. A Zala megyei főispán, Bosnyák Géza a horvát lakosságú Muraközben hirdetett ostromállapotot. Itt is város és falu háborújáról volt szó: a horvát falvak kiéhezett népe fenyegette a kisvárosok magyar és zsidó polgárságának vagyonát. „A falvakban házkutatásokat tartanak, a gyanús holmikat összehordják a község középére, odahívják az egész falu népét, magyarul és horvátul kihirdetik a statáriumot. Eleinte nem nagyon hatott a fenyegetés, de mikor egy-két rablót a községháza előtt felkötöttek, hurcolkodó hangyarajjá változott a legtöbb muraközi falu. Az elrabolt holmikat, még a pénzt is majdnem mindenült hiánytalanul visszaadták a tulajdonosoknak." ${ }^{64} \mathrm{Nem}$ tudjuk pontosan, hány ember esett áldozatul a sommás eljárásnak; a december 6-i kormányülésen Kunfi Zsigmond 134 kivégzésről beszélt. Az eljárás valóban nem illett egy demokratikus népkormányhoz, és végső soron hatástalan is volt. Bár a rablott holmik nagy része megkerült, a magyar uralmat Muraközben sem sikerült megvédeni. A fenyegetett délszláv lakosság védelmének jelszavával a szerbek decemberben Csáktornyára és Muraszombatba is bevonultak. A véres rendcsinálás Erdélyben is alkalmat adott a nemzetiségi sérelmek világgá kürtölésének. Különösen a jósikafalvi esetnek támadt erős visszhangja, ahol Urmánczy Nándor földbirtokos, Károlyi egykori híve egy Budapesten toborzott alkalmi zsoldossereg segítségével torolta meg bátyja birtokának kirablását. Itt is több tucat fosztogatót végeztek ki - akik történetesen románok és cigányok voltak -, holttesteiket pedig elégették. A nem sokat teketóriázó „ítéletvégrehajtók” között ott volt a később finom tollú történésszé érett Asztalos Miklós is. ${ }^{65} \mathrm{~A}$ falubeli rosszfiúk félig elszenesedett tetemeiről szóló híradások a román nemzetiségi vezetőknek kiváló alkalmat adtak arra, hogy az ügyet nemzetiségi sérelemként, „románirtásként” továbbítsák a párizsi antantszalonokba. ${ }^{66}$

Az elharapódzó erőszakoskodások itthon is a legkülönbözőbb politikai diskurzusoknak biztosítottak termékeny táptalajt. A Szentgáli-különítmény kegyetlen megtorlása a szabolcsi Tiszadobon a szerveződő kommunistáknak szolgáltatott ürügyet a népnyúzó ellenforradalom látványos szapulására, a „cionista gárdának” nevezett karhatalmi egységek részvételével elkövetett, tucatnyi halálos áldozatot eredményező dorogi és alsónémedi önbíráskodás pedig az ellenforradalmi korszak antiszemitizmusának nyújtott mohó kézzel megragadott ideológiai muníciót. ${ }^{67} \mathrm{Ami}$ ma hihetetlennek látszik, az akkor megtörtént: a hazatérő parasztkatonák és aszszonyaik ámokfutása 1918 őszén egy rövid pillanatra összehozta a fehér különítményesek tisztjeit a zsidóság önvédelméért fegyvert fogó cionista gárda tagjaival. A különben liberális hajlamú miniszterek pánikban fogant statáriális intézkedéseit pedig nagyrészt szocialista munkásosztagok hajtották végre. A korszak „nagy félelmének” tárgya a parasztság ismeretlen, mélységben morajló valósága volt, ami kirajzolta a ma-

\footnotetext{
Statárium Zala megyében. Az Ujság, 1918. november 21.

65 Ablonczy Balázs: Ismeretlen Trianon. Budapest, Jaffa, 2020.

66 Lásd: Komáromi János: Jászi Aradon. Új Magyar Szemle, (1920), 1. 31.

67 Lásd: Az alsónémedi vérfürdő. Szózat, 5. (1923), augusztus 26.; Saskeöy József: Az alsónémedi eset. Világ, 14. (1923), 193. 2. A dorogi esetre lásd: Persián Ádám kormánybiztos visszaemlékezései i. m. 17-18.
} 
gyar jövő következő fél évszázadát, a parasztság elkerülhetetlen bevonását a nagypolitikába és belépését a kulturális kánonba: a népi mozgalom megszületését. Illyés Kora tavaszát, Németh László Kocsik szeptemberbenjét és Kodolányi János sötét tónusú ormánsági novelláit. A Károlyi-kormányban ezt Jászi Oszkár ismerte fel a leginkább, a földreform azonban nemcsak a jussukhoz foggal-körömmel ragaszkodó nagybirtokosok, hanem a parasztságot bizalmatlanul kezelő szociáldemokraták miatt is hónapokat késett. A vidék bolsevizálódásától való félelemnek egyébként nagyobb volt a füstje, mint a lángja: a paraszti erőszak „úri” áldozatainak száma országosan talán az 50 főt sem érte el, miközben legalább 1000 névtelen ember vesztette életét a statáriális kivégzések és megtorlások nyomán. ${ }^{68}$ Többen, mint az 1919-es vörös-, és közel annyian, mint a fehérterror idején, csak míg ez utóbbiakról azóta is tart az ideológiai számháború, addig a vidék 1918. őszi parasztforradalmának bűnös és ártatlan halottai kihullottak az emlékezetből. Az erőszak történelme egyaránt igazságtalan tettessel és áldozattal. Ha azonban összehasonlítjuk a történelmi Magyarország területén végbement erőszakot Kelet-Európa tágabb térségeivel, azt látjuk, hogy a Szovjetunió megalakulásához vezető orosz polgárháború 3 millió áldozatot szedett (a lakosság 2\%-át), hogy az 1918-as finn polgárháború erőszakos halált halt áldozatainak száma 36 ezer, azaz a lakosság több mint 1\%-a, hogy az I. világháborút követő baltikumi harcok során egyedül Riga ostrománál 3000 embert végeztek ki a várost elfoglaló Baltische Landeswehr tiszti különítményei 1919 májusában, hogy a lengyel-ukrán-orosz határvidéken az 1918-1920 közötti pogromok 100 ezer zsidó polgár életét oltották ki, hogy Elszász-Lotharingiából a bevonuló franciák néhány hónap alatt 200 ezer németet telepítettek erőszakosan ki, ${ }^{69}$ és hogy a görög-török háborúk nyomán mindkét részről előfordult több tízezres nagyságrendű genocídium, úgy azt kell látni, Szent István birodalmának felbomlása, az 1918-1921 közötti látens polgárháború politikai és társadalmi konfliktusai valójában és objektíven kisebb megrázkódtatást okoztak, mint azt a hivatalos emlékezet számon tartja.

\section{Károlyi Mihály demokratikus kísérletének kudarca}

Aligha volt a magyar történelemben kevesebb hatalommal rendelkező „diktatúra”, mint amilyen Károlyi Mihály mostoha sorsú népköztársasága volt. Hatalmát és igazolását eleinte a közvetlen demokrácia példátlan méretű megnyilatkozására, a spontán módon létrejött helyi nemzeti tanácsok százainak önkéntes munkájára alapozhatta, de a forradalmi önigazgatás színes és anarchikus világa igencsak kétarcú volt. A nemzeti tanácsok sokszor szinte önálló köztársaságokként viselkedtek, a vasútállomásokon lefoglalták az áthaladó szállítmányokat, megtiltották a termények kivitelét

68 Schönwald (1969) i. m. 351. Lásd még: Hajdu (1968) i. m. 145.; Nemes Dezső: A Kommunisták Magyarországi Pártjának létrejötte és kezdeti tevékenysége. Párttörténeti Közlemények, 28. (1982), 4. 12.

69 Tara Zahra: The 'Minority Problem' and National Classification in the French and Czechoslovak Borderlands. Contemporary European History, 17. (2008), 2. 139. 
a falu határain túl, vagy éppen ellenséges hadviselő felek módjára indítottak tárgyalásokat egymással. A két szomszédvár, Hódmezővásárhely és Szeged nemzeti tanácsai „nemzetközi” tárgyalásokat kezdtek sertések és a zsír átengedése tárgyában. ${ }^{70}$ Az eltűnő állami hatalom hordalékos senkiföldjén kérészállamok rövid életű konjunktúrája következett, bánáti, zsil-völgyi, szepességi, hucul, kun köztársaságokkal. Egyik-másik csak papíron létezett, de a legkomolyabbra, a Székely Köztársaság megvalósítására rengeteg pénzt is adott a Károlyi-kormány. A régi Magyarországot nem mentették át a hősies területmentő koncepciók, és a helyi elitek is hasztalan próbálkoztak újfajta nemzeti identitást adni szúkebb pátriájuknak - a politikacsináló kevesek éles nemzeti törésvonalai mögött a tömegek „a nemzeti közömbösség” mindennapos valóságát élték. ${ }^{11} \mathrm{E}$ válságos hónapokban többször is bebizonyosodott, hogy 100 év nemzeti ébredése és ébresztése aligha formálta egységesen maga képére a társadalmat, a falusi Magyarországon továbbra is addig terjedt a haza, ameddig a harang szava elhallatszott. ${ }^{72}$ A politikát a városon és falun utca és alvég jogérzéke diktálta, a pesti kaszárnyák fegyelmezetlen katonanépe hadügyminisztereket buktatott, a többszöri nekifutásra is sikertelen hadseregszervezés helyett a paramilitáris és pártmilíciák konjunktúrája következett. Nemzetőrség, Védőrség, Népőrség, Bankőrség, Gyárőrség, „Cionista Gárda”, Csepelen Vörös Gárda stb., sőt az antialkoholista egyesületek tagjaiból Friedrich István hadügyi államtitkár még Egészségügyi Népőrséget is szervezett, többé-kevésbé hivatalos áldással. (Ez utóbbi tagjai olyan magas napi zsoldot kaptak, hogy akár 3 liter rumot is vehettek rajta. Valószínúleg vettek is, de a visszaemlékezések általában úgy szólnak, hogy nem vettek.) ${ }^{73}$ Leginkább Gabriel García Márquez regényeiben szereplő hadurakhoz és seregeikhez lehet tehát a káoszban szerveződő fegyveres különítményeiket és parancsnokaikat hasonlítani, miközben Budapesten továbbra is múködött a rendőrség, vidéken sok helyütt a csendőrség is, igaz mindkettő árnyéka volt korábbi önmagának. A népuralom a munkanélküliek szaporodó seregei számára üres szó volt, felvonulásaik, a háborúból hazatért rokkantak zajos deputációi átjáróházzá tették a miniszteri fogadószobákat, a vezérétől nemsokára magára hagyott Károlyi-párti politikusokat büntetlenül pofozták fel szocdem kisvezérek.

„Trianon” - az ország széleinek megszállása Trianon előtt következett be. A szerbek már 1918. november közepén birtokba vették a Délvidéket, a románok karácsonykor már Kolozsváron voltak, a csehek szilveszterre Kassa, újév másnapjára Pozsony urai lettek. A napról-napra zsugorodó területű országban a közvélemény - közöttük a megszállt területekről tízezrével érkező menekült tisztviselők - a régi bajokat az új orvosok tehetetlenségén kérte számon. Egyre hangosabban, mégis inkább színpadi-

\footnotetext{
70 Tonelli Sándor: A franciák Szegeden: 1918 december - 1920 március. Acta Universitatis Szegediensis: Sectio Geographico-Historica, 7. (1939), 1. 34-35.

71 Berecz Ágoston: Recepciótörténeti széljegyzet Tara Zahra tanulmányához. Régió, 25. (2017), 2. 43-50.

72 A pacsai főszolgabíró jelentése a a bolseviki mozgalom története. Pacsa, 1921 október 5. K46 PTI 605 f II635 I. kötet.

73 Wessely László: Egy diák a forradalmakban. In Bakó Ágnes - Erényi Tibor - Szabó Ágnes (szerk.): Tanúságtevők. Viszszaemlékezések a magyarországi 1918-1919-es forradalmak résztvevőiról. Budapest, Kossuth, 1978. 243.
} 
asan, mint veszélyesen. A növekvő középosztályi ingerültség jórészt passzív maradt, az „ellenforradalom” a polgári lakások hideg hálószobáinak mélyén kuksolt, nyilvános szavait pedig óvatosan megválogatta. A leszerelés és a forradalom nyomán 8000 tényleges tiszt egzisztenciája vált bizonytalanná - közülük csak 2700 húzott továbbra is fizetést az államtól, a többieket nyugdíjazták, a fötiszteket és a tartalékosokat rövid úton leszerelték. ${ }^{74} \mathrm{~A}$ megélhetés nélkül maradt tényleges tiszteket és a továbbszolgáló altiszteket tömörítő Magyar Országos Véderő Egyesület januári 19-i közgyúlésén Gömbös Gyula kibontotta a nacionalizmus megtaposott zászlaját, de a Népszavának azt nyilatkozta, hogy a MOVE-ban nem tűr reakciót és ellenforradalmat, híve a népköztársaságnak és a nemzeti szociális iránynak. Jól is tette, egy jobboldali erőközpont létrehozására ekkor még Bethlen István gróf kifinomult politikai tehetsége sem volt képes. A Nemzeti Egyesülés Pártja ugyan létrejött 1919 februárjában, de az egység szava a jobboldalon még nem tudott egy zászlót és egy tábort teremteni.

A Károlyi rendszer forradalmi demokráciája is az utolsókat rúgta. Hiába tűnt úgy 1919 februárjában, hogy a földreform végre elindul, hiába döntöttek a választások kiírásáról március elején, a kampány minden piszkos kellékével el is indult, valódi demokratikus politikai verseny mégsem bontakozott ki. A nem szocialista jelöltekkel szembeni egyre erősödő zaklatások oda vezettek, hogy Károlyi legodaadóbb hívei is az azonnali távozásra gondoltak már, Böhm Vilmos viszont akadémikusnak minősítette a kérdést azzal kapcsolatban, hogy mi lesz, ha mégsem nyernek a szocialisták. Helyette a Népszava vezércikke válaszolt félreérthetetlen hangnemben: a parlamenti választások tétje, hogy békés vagy erőszakos eszközökkel valósul meg a szocializmus, amelynek bekövetkezése kikerülhetetlen történelmi és gazdasági szükségszerüség, és ha ezt a szavazók nem értenék meg, és a Szociáldemokrata Párt kisebbségbe kerülne, akkor „el fog következni az erőszakos felforgatások végeláthatatlan korszaka”. 75

„[F]orradalmat akarunk, olyat, amilyent az oroszok csináltak.” A bolsevizmus korai története Magyarországon.

A Népszava idézett cikke egy több hónapos folyamat végére tett pontot. Azt illusztrálta, hogy a magyar politika demokratikus kibontakozásának lehetőségét a bolsevizmushoz való viszony lefagyasztotta - a szociáldemokrata párt egy-két Garami körül maradt, és egyre jobban elszigetelődő vezetője kivételével szakítani akart a demokráciával, aminek eléréséért két évtizedig küzdött. A kommunizmus új szó volt 1919-ben, és jelentésébe sok minden belefért. „Nem volt elméletünk” - írta meg Lengyel József a proletárdiktatúra fontos kulcsregényében: „Egyet tudtunk: forradalmat akarunk, olyat, amilyent az oroszok csináltak." ${ }^{76} \mathrm{Az}$ orosz mánia először is szenvedélyes olvasmányélmények lecsapódása volt. „Minden könyv, amit a múlt században orosz kéz írt: titkos propagandája egy közelgő új világnak” - vélte Krúdy Gyula, aki szerint Orosz-

\footnotetext{
74 Dósa Rudolfné: A MOVE megalakulása és tevékenysége az 1918-as polgári demokratikus forradalom időszakában. Hadtörténelmi Közlemények, 15. (1968), 3. 464-467.

75 A politikai és gazdasági hatalom. Népszava, (1919), 67. 1.

76 Lengyel József: Visegrádi utca. In Lengyel József: Mérni a mérhetetlent. I-II. kötet. Budapest, Szépirodalmi Könyvkiadó, 1966. II. 24.
} 
országban 100 esztendeig tartott az emberiséget megváltó forradalom előkészítése, Dosztojevszkij és Tolsztoj regényei pedig „bombák” voltak. ${ }^{77}$ A fiatal Lukács György szintén Dosztojevszkij könyveiben találta meg az „orosz eszmét”, amely a kötelességek rideg világából mindenkit átvezethet a jóság és szeretet egyetemes erkölcsének hatalmába. ${ }^{78}$ Kivétel nélkül mindenkit. Ilyen csak könyvekben létezik, de a könyveknek nagyobb hatalma van olvasóik felett, mint a valóság káoszának. S a könyvek hatalma aligha becsülhető túl a bolsevik gondolkodás forrásvidékein. ${ }^{79}$ Krúdy a proletárdiktatúra első hetében bevallotta, hogy ifjúságában az orosz írókat még a nőknél is jobban szerette, de minden könyvnél és könyvmolynál fontosabb volt, hogy mit gondoltak és mit mondtak a lenini Szovjet-Oroszországból százezrével hazajött hadifoglyok itthon a családjuknak, falubelijüknek, vagy külvárosi rossz kocsmák pultjainál egymásnak. Az ő érdes elbeszélésük a háború merész, birodalomromboló befejezéséről és a földosztásról szólt, valamint a haragról, a nyomor felelőseivel való büntetlen leszámolásról, amelyben a jövő új világa és a szegény ember igazsága rejtőzik. ${ }^{80}$ Ez utóbbit a felsőőri járásban fekvő Vasvörösvár környéki falvak hadviselt kisgazdái az Erdődy grófok hatalmas uradalmi erdején próbálták ki. „A kommunizáláshoz hozzá is fogtak olyképpen, hogy a faluk lakossága szekérszám vitte el a fát az erdőből” - írta az egykori tudósítás, a közbelépő csendőrökre pedig olyan bátorsággal lövöldöztek, mintha még mindig az olasz hadszíntér fennsíkjain lettek volna. ${ }^{81} \mathrm{Az}$ „orosz példa” Magyarországon is az egyenlőtlen tulajdonviszonyok talaján szökkent szárba, s elsősorban a hagyományos társadalmi helyzetéből amúgy is kiragadott frontot járt és/vagy az orosz hadifogságból visszatért katonaság és családjaik körében terjedt. Lenin bolsevizmusa egyszerû receptet kínált a veszteseknek: állj bosszút, s akkor tied a jövő! Azonban a háborús vereség másnapján 1918-1919 fordulóján már nemcsak a hazatért és helyüket nem nagyon találó bakáknak, hanem majdnem mindenkinek megvolt a maga „bolsevizmusa.” Egyrészt és főleg a kegyetlen győztesekkel szemben, másrészt mindenki ellen, akiben ellenséget vagy jobban élő vetélytársat vélt látni. ${ }^{82}$

77 Krúdy Gyula: Orosz hangok. Magyarország, 26. (1919), 76. 4.

78 Perecz László: „Gyönyörű víziója egy igazán emberi világnak” (Lukács György 1919-es kommunizmus-képéről). Magyar Filozófiai Szemle, 33. (1989), 5. 541.

79 Yurii Slezkine: The Jewish Century. Princeton, Princeton University Press, 2004. 224., illetve 163., 129.

80 „Kunhegyesről hiteles feljegyzések alapján a több mint 4 éves háború alatt 2581-en teljesítettek katonai szolgálatot. 676-estek fogságba, ezek közül 385-en orosz hadifogságba. A breszt-litovszki béke utat nyitott a fogságban lévőknek, 1918. október 31-ig a forradalom kitöréséig a 385 orosz fogoly közül 302 szerencsésen hazatért. A hazatérők kevés kivétellel telítve voltak kommunista elvekkel. Az Asiago melletti és a Piave menti offenzívák véres veszteségeit az orosz hadifogságból kiszabaduló katonákkal pótolta a hadvezetőség. A Kunhegyesre visszatért foglyok alig pár heti szabadság után ismét a frontra kényszerültek visszamenni. Elkeseredés gyülölet szikrázott a szemekből, összeszorított ököl emelkedett az ég felé, amikor egy hadifogságból sok-sok viszontagság után hazatérő megkapta a behívót. A bolsevizmus honában magukba szívott veszedelmes tanok lassanként megérlelődtek lelkükbe és csak kitörésre vártak. Ehhez járult az elveszett háborúval járó rettenetes lelki depresszió, az 1918 évi rossz gazdasági esztendő, mely elkeserítette a szegényebb néposztályt, de csüggedté tette a birtokos osztályt is." A bolsevizmus előkészítése és lefolyása Kunhegyesen. Masát Ferenc kunhegyesi ref. lelkész 1921. január 15-i jelentése az 1919-es eseményekről. MNL MOL K46 PTI 605.f. II/32 őe, 73-75.

81 A Vasmegyei Hírlap 1919. február 25-i Csata a vasvörösvári erdókben című tudósítását újraközli: Dokumentumok és viszszaemlékezések 1918-1919 hősi harcaira. Társadalmi Szemle, (1959), 2. 92.

82 Vincze Sándor: Az erdélyi forradalom. I-II. PIL 965.f. 1., II. 402. 
A bolsevik szótárban az ellenség megnevezése a burzsoá lett - orosz alakjával, a „burzsujjal” és az ebből továbbképzett „burzsival”együtt 1918 elejétől kezdve terjedt el az újságok lapjain -, és szinte bármely összefüggésben képes volt mozgósítani az indulatokat, mert a politikai irányítás lefagyásával szemben a társadalmi élet „egész anyaga cseppfolyóssá vált”. ${ }^{83}$ A városi háztulajdonos a falusi földbirtokos kárán örvendezett, akinek frontról hazatérő béresei felgyújtották a magtárait, a kisgazdák a házbér zárolásának örültek kárörvendően, a nyomorgó értelmiségiek pedig a vagyon tűnő csillagán gyönyörködtek. ${ }^{84} \mathrm{~A}$ Károlyi-kormány szűk öt hónapos létezése idején a magyar fizetőeszköz, a korona zürichi árfolyama a felére csökkent a svájci frankkal szemben. ${ }^{85}$ A városi piacokról eltűnt a zsír, a szalonna és a tej. A bolsevizmus a harag gyakorlati filozófiája volt, és hazai forgalmazóinak rendkívüli mértékben a kezére játszott, hogy a háború utáni viszonyok még a háborús viszonyoknál is elkeserítőbbnek tûntek. Kiderült: az egyszer elért életszínvonal elvesztése sokkal forradalmasítóbb hatású, és sokkal szélesebb rétegeket érint, mint a nagyüzemi munkásság évtizedes politikai törekvése életszínvonala folyamatos javítására. ${ }^{86}$ Tüntettek a házmesterek, hogy ingyen többé nem zárják el éjjelre a vízvezetéket, sztrájkoltak a pincérek, hogy egyenlő fizetést kaphassanak a szűkmarkú borravaló helyett, és lázongtak a csepeli és soroksári hadiüzemek munkásai, mert a háborús konjunktúra leáldozásával féltek a békében óhatatlanul bekövetkező munkanélküliségtől. ${ }^{87}$ Hiába törekedett Garami Ernő az „ipari békére”, hiába hozta létre minisztériuma a kollektív szerződések százait munkaadók és munkavállalók érdekképviseletei között olyan szakmákban is, amelyek korábban alig léteztek a munkásmozgalom számára, hiába tágult minden elképzelhetőnél szélesebbre a munkásellenőrzés intézményi lehetősége, szocializmus és kapitalizmus nem léphetett okos és megfontolt érdekházasságra a szenvedélyek kollektív dühöngésével szemben. ${ }^{88} 1919$ telén biztosan nem. A kormány plakátjai a többlettermelésről prédikáltak, de a nagyüzemek gyári munkása az izzasztó teljesítménybér helyett nyolcórai munkát akart, és a kommunista agitátorok azt suttogták a fülébe: Lenin Oroszországában mindez már valóság. A polgárháború káoszában vergődő Oroszország bolsevik valóságáról hiteles információk persze nem jutottak el sem a Ganz-gyár esztergályosaihoz, sem a körúti viceházmesterek alagsori lakásaiba, így a kommunista propaganda a benne rejlő indulati-érzelmi potenciált könnyen fordí-

83 Kunfi Zsigmond: A legyőzöttek [1928]. In Köves Rózsa - Erényi Tibor: Kunfi Zsigmond életútja. Budapest, Kossuth, 1974. 351.

84 Giczey György százados visszaemlékezése Visszaemlékezések a Nemzeti Hadsereg megalakulásáról 1921. március 28. HIL TGY 2.953. 12.

85 Mészáros Károly: Adalékok a Tanácsköztársaság gazdasági-pénzügyi helyzetének alakulásához, a város és falu közötti termékcseréhez, rekvirálásokhoz. Párttörténeti Közlemények, 8. (1962), 3. 39.

86 Varga Jenő: A proletárdiktatúra gazdaságpolitikája. In Varga Jenő: Válogatott írások 1912-1922. Budapest, Kossuth, 1976.

87 A házmesterek és pincérek mozgalmára l. Debreczeni-Droppán Béla: 1919 forró tavasza a pesti Múzeumkertben. újkor. hu, 2019. március 21. A csepeli és fegyvergyári munkások radikalizálódására lásd: Bajáki Ferenc 1920. július 10-i vallomása a Népbiztos-perben. BFL. VII. 5.c 1920-6274, XXXIII. dosszié, 1837-1849.

88 Kende János: A szakszervezetek szerepe a Tanácsköztársaság államában. Párttörténeti Közlemények, 1974.1974 / 4. 70. Vö. Péteri György: A „tudományos üzemvezetés” és a munkásellenőrzés konfliktusa 1919-ben. Történelmi Szemle, 22. (1979), 1. 43-44. 
totta át elméletieskedő könyvfilozófiából a mindennapok túlélésének gyakorlatias meggyőződésévé. „Minden ember kommunista. Annyi a különbség ember és ember között, hogy az egyik tisztában van kommunista tudatával, a másik meg mit sem sejt róla” - ezt a könnyen emészthető népi bölcsességet egy egyszerű vörösőr osztotta meg néhány hónappal később a nyugati határszélen, a Lajtánál az olasz szocialista funkcionáriussal, Oddino Morgarival. ${ }^{89}$ A bolsevik igék lehetővé tették, hogy mindenki meglássa magában a „proletárt” és ellenségében a „burzsoát,” ráadásul Lenin világossá tette, hogy a munkásosztály is csak kívülről, a forradalmi élcsapat révén ébredhet „osztálytudatára”. A forradalmi élcsapat pedig az egész népet vezeti a szocializmusba.

A bolsevik elbeszélést leghatásosabban Magyarországon is pár tucat friss kommunista formálta, akik többségükben szintén hadifogságból tértek haza, de véglegesen megváltozva, a világforradalom ügynökeiként. Az utólagos eredetmítoszok heroizáló elbeszéléseivel ellentétben ők is csak néhány leckével jártak előrébb a vadonatúj tananyagban. Kun Béla 1915-ben még hazafias cikket írt a Népszavába, „öreg harcosként” a "győzelmes béke” kincstári optimizmusával telve. A tomszki fogolytáborban lehurrogta azt a kolozsvári kőmúves fogolytársát, aki tiszti rangja ellenére egyszerúen elvtársnak szólította: „Nem vagyok elvtárs! Zászlós Úr vagyok!”90 Aztán jött az 1917-es februári forradalom, az orosz összeomlás, a fogolysors szégyene helyett a káosz szabadsága. Azoknak, akik a hirtelen kiismerhetetlenné lett oroszországi viszonyok felfordulásában a bolsevik kártyára tettek, hatalmas lépéselőnyt biztosított, hogy jókor voltak jó helyen. Nem világos, hogy Kun Béla pontosan mikor talált vissza szocdem önmagához, és mikor lett belőle szociálforradalmár és aztán bolsevik, de valamikor 1917 decemberében, amikor a távoli Szibériából Moszkvába utazott, már véglegesen rálépett a lenini útra. Kun moszkvai mentorai - elsősorban Karl Radek, Szverdlov és Zinovjev - körül forgolódva 1918 tavaszán-nyarán villámgyors karriert csinált a Leninék által világforradalmi propaganda célra létrehozott nemzetközi hadifogoly-szövetség élén, s közben maga is alapos kiképzést nyert az agitáció, a propaganda és a konspiráció bolsevik fortélyairól. A tanulást megkönnyítette, hogy a bolsevizmus nemcsak technika volt, hanem egy sajátos erőszakvallás, amely arról szólt, hogyan kell a dühből és frusztrációból fakadó elementáris indulatokat a jövő tökéletes társadalma iránti felfokozott várakozással keverni. „Békét követelünk mi is, sötét haraggal a fehér Szibériából” - fogalmazták meg az omszki hadifogolytábor magyar katonái még 1918 telén, s ez a harag volt Kun Béla és társai szervezkedésének igazi valutája, nem a kabátbélésben és cipőtalpban hazahozott milliók. ${ }^{91}$ Sőt a korai kommunista propaganda egyenesen a halálkultusz jegyében fogant: „[Ö]lni, gyilkolni apáink, testvéreink, a gyermekeink, önmagunk érdekeinek védelmében [...]: van-e ennél szentebb, lelkesítőbb, felmagasztalóbb? [...] Az élet, ami után mi vágyunk, mi törekszünk,

\footnotetext{
89 Pankovits József: Gramsci és 1917. Háború, forradalmak, olasz kommunizmus, fasizmus. Múltunk, (2017), 4. 221222.

90 Borsányi György: Kun Béla. Budapest, Kossuth 1979. 38., 46.; Vincze (é. n.) i. m. 59-60.

91 I. V. Matvejev: Magyar internacionalisták részvétele a szovjethatalom megteremtéséért és megszilárdításáért vívott harcban Szibériában (1917 február - 1921). Századok, 93. (1959), 2-4. 338.
} 
amiért mi harcolunk, az csak a halál nyomán születhet meg. A halál a mi jóbarátunk. [...] A gyávák a hitvány férgek, a kukacjellemúek, a harc elől, a mi felszabadító, szent küzdelmeink elől megfutamodók nem közénk valók. Nincs számukra hely. A halál elől futó, rongy árulók bére nem is lehet más, mint a halál. Akik féltek ismeretséget kötni a halállal, vegyék el jutalmul a mi fegyvereinktől a megváltó golyót. Forradalmi katonák, végezzetek gyorsan és könyörtelenül a megfutamodókkal, s aztán előre. Szempillád meg ne rezdüljön, kezed meg ne remegjen soha: a halál útja a győzelem felé vezet." ${ }^{2} \mathrm{Az}$ egykori kallódó újságíró és szintén hadifogoly Szamuely Tibor - aki Kunhoz a legelsők között csatlakozott - még Moszkvában írta ezeket a sorokat az első magyar nyelvü kommunista lapba, de a korabeli bolsevik death metal hörgése az orosz polgárháború vérrel borított mezőiről minden szűrő nélkül került át a budapesti politikai nyelvbe is. A november közepén Moszkvából kalandos úton hazatért Kun Béla nagyon gyorsan építette ki a Kommunisták Magyarországi Pártját, amely szabadnak érezte magát minden demokratikus vagy parlamentális kötöttség alól. „Mindenki ott üssön agyon egy ellenforradalmárt, ahol éri” - rikoltotta a Vörös Újság címlapja, $s$ a gátlástalan gyúlöletbeszéd revolver-újságíróinak azt sem esett nehezükre kimondani, hogy „pusztuljon a népkormány!”. ${ }^{33}$ Kun hazaindulása előtt egy héttel, a központi bolsevik napilap, a Pravda hasábjain oroszul adta meg a magyar őszirózsás forradalom bolsevik értelmezését: Károlyi és „népkormánya” nem egyéb, mint Kerenszkij és az 1917-es balul végződött orosz polgári demokrata kísérlet magyar kiadása. Találó párhuzam volt. Károlyi az orosz pályatárshoz hasonlóan, szintén a reakciós rendszer ellenzékéből jött, és ahogy Kerenszkij, úgy Károlyi sem volt arra képes, hogy feladja a régi rendszertől örökölt háborús célokat. ${ }^{94}$ Kerenszkij a bukott cár imperialista háborújából patrióta honvédelmet akart csinálni, de a frontkatonákban ekkor már inkább gyülölet volt, mint nemzethűség, s az 1917-es nyári Kerenszkij-offenzíva gyors összeomlása nemsokára elhozta névadójának is a biztos bukást. A Károlyi-kormány hivatalba lépésének első napján szintén hazafias bizakodással osztotta meg a „nemzettel”, hogy „sikerülni fog megmenteni az ország területi épségét”. ${ }^{95}$ Mire Kun Béla november 17-én Budapestre érkezett, kiderült, hogy nem sikerült. Míg Kerenszkij a hadsereg patrióta mozgósításával valott kudarcot, Károlyi a pacifista retorikájával. A kommunista vezér diagnózisa a lényegre tapintott rá: az antantorientáció és a területi egység megóvására egyszerre irányuló politika katasztrofális ellentmondást hordozott magában.

Kun Moszkvában megtanulta, hogyan kell az ábécéskönyvek egyszerúségével megfogalmazni politikai üzeneteit. „Ki fizet a háborúért?”, „Mit akarnak a kommunisták?”, „Mi a Tanácsköztársaság?”, „Kié a föld?”. A Kommunista Könyvtár orosz

\footnotetext{
92 Szamuely Tibor: Riadó. Szociális Forradalom, 1918. augusztus 10. Újraközli: Szamuely Tibor: Riadó. Budapest, Kossuth, 1957. 22.

93 Üssétek agyon... Vörös Újság, (1919), február 11. 1.

94 A magyar „Kerenszkij-uralom” [Vengerszkaja Kerenscsina] címmel a Pravda 1918. október 31-i és november 1-jei számában oroszul megjelent cikket magyar fordításban A magyar októberi forradalomról címmel közli Kun Béla: Válogatott írások és beszédek. I. k. Budapest, Kossuth, 1966. 180-187.

95 A nemzethez. Világ, (1919), 123. 1., illetve Károlyi proklamációja Magyarország népéhez. Világ, (1919), 69. 5.
} 
pénzen nyomott kis alakú vékony füzetei jól összefoglalták a lényeget, amelynek sztárszerzői is a politika új orosz professzorai, Lenin, valamint Nyikolaj Buharin voltak. A 31 éves Buharin 1918-1919-ben az orosz bolsevik párt kedvence volt, amolyan ideológiai helyettes főszakács Lenin örökké sistergő konyhájában, s még nem tudta, hogy a kommunista vezető életére a kommunista rendszer lehet a legveszélyesebb, sem azt, hogy 20 évvel később Sztálin vérbírói előtt állva az utolsó szó jogán azt fogja kérdezni magától „milyen ügyért fogsz meghalni?”. Az „Ügy” 1919-ben az egész emberiség ügye volt, és Buharin szerint az emberiség csak olyan feladatot tűz ki maga elé, amelyeket meg tud oldani. Buharin soraihoz 1919 januárjától már Budapesten is minden utcai lapárusnál és dohányboltban hozzá lehetett jutni. A világforradalom orosz hitvallásának ára 2 korona volt, és csillogó késekkel közeledő leszámolást ígért: „A viszonyok összessége. amely Európában kialakult, ehhez az elkerülhetetlen célhoz vezet. Így az állandó orosz forradalom a proletariátus európai forradalmába megy át, melyet ugyanaz az imperialista állam fegyverzett fel, amelynek fejére a guillotine [nyaktiló] csillogó kését felemeli." ${ }^{\prime 6}$

A társadalom szövete ugyan bolsevizálódott, de Kun Béla és elvtársai mögött egyetlen jelentős csoportja sem állt, még a nagyüzemi munkások sem. A munkásság egyik vidéki fellegvárában, Ózdon például létre sem jött kommunista szervezet, de Győrben, a legnagyobb dunántúli iparvárosban is alig akadt 15-20 munkás 1919 március elején, aki elment volna a fővárosból hozatott kommunista szónokot meghallgatni. ${ }^{97} \mathrm{~A}$ bolsevik igékkel az újpesti gyárakban is felsült a rajongó Sinkó Ervin, a kommunista alapítók között mutatóban akadt csak valódi fizikai munkás, mint Mikulik József vagy Mosolygó Antal a mátyásföldi repülőgépgyár bizalmija. Kun Bélát ez nem feszélyezte. „Csak a vezetőknek kell érettnek lenni a nagy történelmi feladatra, a proletárdiktatúrában a vezetők az osztály nevében és képviseletében korlátlan hatalommal rendelkeznek" - mondta egykori kolozsvári elvtársának, Vincze Sándornak. ${ }^{98}$ A párbeszéd a Népszínház utca és a József körút sarkán álló Simplon Kávéházban zajlott, amely irodalmi törzsasztalaival később nevezetes tanyája lett a magyar íróknak, ekkor még inkább színház utáni bő vacsorák színtere. Kun jól szabott zsakettet viselt, és gondosan megkötött nyakkendőt. Megjelenése jólétet sugárzott. Amikor Vincze a demokráciára figyelmeztette, nyugodt hangon felelt: „A demokrácia burzsoá hazugság." ${ }^{99}$ Vincze elképedve hallgatta a választ, de rabul ejtett értelmével korántsem volt egyedül, a bolsevik kommunizmussal szemben egyre többen szorultak defenzívába. A szocdem vezetők többsége lanyha és meggyőződés nélküli kedvvel küzdött a kommunista járvány ellen, mások, mint a kőművessegédből lett építőipari szakszervezeti vezetők, mint Garbai Sándor vagy Bokányi Dezső nyilvánosan kiosztott csattanós pofonokkal. A jobboldalról érkező antikommunista kiállás viszont azonnal ellenforra-

\footnotetext{
96 Nikoláj Bucharin: Az imperializmus diktatúrájától a proletárdiktatúráig. Budapest, Kommunisták Magyarországi Pártja, 1919. 4.

97 Mi a kommunizmus? Testvériség, 2. (1919), 11. 1.

98 Vincze (é. n.) i. m. 61.

99 Vincze (é. n.) i. m. 62.
} 
dalmi bélyeget ütött megfogalmazójára. Január folyamán több polgári lap szerkesztőségét is feldúlták, a Déli Hírlapra irányuló konzervatív polgári felvásárlási kísérletetet kormányzati támogatással akadályozták meg a lap szocialista újságírói, és az 1918-1919 fordulóján kibontakozott „médiaháború” nemcsak a „keresztény” politikát követelő Bangha páter törekvéseit törte le az Apostol-nyomda gépeinek és berendezéseinek szétverésével, hanem margóra szorította a konzervatív és liberális politikai alternatívákat is. ${ }^{100}$ Egyedül a szakszervezeti lapok mertek riadót fújni keresetlen nyersességgel: „A munkásmozgalom vizein a kommunizmus hamis lobogója alatt kalózhajók cirkálnak, hogy örvénybe taszítsák a a jó utakon haladó, a kommunizmust elérni akaró szociáldemokrácia hajóját” - írta a Famunkás vezércikkírója, aki éles kirohanást intézett „a pártütő rubellovagok”, a „megkergült fiskálisok” és „törtető mérnökfiókák” ellen, „akik az ébredő magyaroknál is mocskosabban gyalázzák a magyar munkásság dicsőséges harcát". ${ }^{101}$ Hasonló hevességgel támadta az újsütetű prófétákat a Vas-és Fémmunkások Lapja is: „[I]de állanak a munkásság elé, föltolakszanak a szónoki emelvényre és adják a hőst, a rettenthetetlen orosz forradalmárt, adják színészi pózban az új Mózest, aki eljött, hogy Izrael népét az ígéret földjére vezesse [...] Honnan szerezték ezek az emberek a jogot, hogy itt tolakodjanak, hogy itt mindenkit szamárnak, árulónak, gyávának és butának bélyegezzenek, a munkástömegek előtt bemocskolják és a munkásságot a maguk ismeretlen céljai felé vonszolják?”102 De hiába tette ez utóbbi cikk szerzője a kommunizmus szót idézőjelek közé, a szocialista érvelés is addig tartott, mint a 30 ezer holdas egykori nagyúré, Károlyi Mihályé: még nem jött el a kommunizmus ideje, azt csak akkor vezethetjük be, ha más országok már megtették. Utólag könnyebb meghúzni a választóvonalat a szocialista eszkatológia reformista és revolucionista olvasatai között, de akkor ez utóbbi még kirakatlan puzzle-játék volt, a kortársak többsége annyit látott: a „tempóban” van csupán különbség kommunisták és szocialisták között. ${ }^{103} \mathrm{~A}$ kommunizmus démoni metafizikája abban ütközött ki igazán, hogy lelkiismeret-furdalást ébresztett: a minden erkölcsöt felrúgó kommunista taktika a politikai felelősség posztjaira csupán nemrég érkezett szocdem politikusokban bűntudatot keltett a szakadár „testvérpárttal" szemben, amelynek tagjai Leninnel és a bolsevikok tekintélyével takaróztak. Akik a siker vakmerő receptjét anélkül reklámozták, hogy a káros mellékhatásokról szóltak volna. Ezért is volt a határozottság hiánya, ezért volt, hogy még Garami Ernő is csak vonakodva egyezett bele abba, hogy a rendőrség tájékoztassa őt a kommunisták törvényellenes üzelmeiről. ${ }^{104}$ Határozott akcióra csak akkor került sor, amikor 1919. február 20-án mintegy 1500 főnyi tömeg támadta meg a Népszava Conti

100 Klestenitz Tibor: Médiaháború 1919-ben: a Déli Hírlap ügye. Médiakutató, (2008), 1. 69-80. Vö. Gellért Oszkár 1920. január 20-i rendőrségi tanúvallomásával BFL VII. 18. d. 1919 - 13 - 8784 Károlyi Mihály elleni zárlati ügy, 36.

101 Szocializmus vagy „kommunizmus”? Famunkás, (1919), február 1. 1.

102 A „kommunisták” és mi. Vas-és Fémmunkások Lapja, (1919), január 2. 1.

103 Peter Kenez: Coalition Politics in the Hungarian Soviet Republic. In Andrew C. Janos - William B. Slottman (eds.): Revolution in Perspective: Essays on the Hungarian Soviet Republic of 1919. Berkeley, Los Angeles, University of California Press, 1971. 62-63.

104 Garami (1922) i. m. 105. 
(ma: Tolnai Lajos) utcai székházát, és lövöldözés tört ki, amelynek nyolc halálos áldozata volt, köztük két rendőr és hárman a népőrségből. Azt, hogy ki lőtt először, világosan megállapítani nem lehet, de szinte bizonyos, hogy a Népszava megtámadására Kun vagy valamelyik alvezére - valószínűleg Vágó Béla - adta ki a felszólítást azon a gyúlésen, amelyet az eseményt megelőzően a munkanélküliek tartottak a Pesti Vigadóban. Az éppen ülésező kormány a szociáldemokrata minisztereire bízta, mi legyen, és ők - a távol lévő Kunfi kivételével - úgy döntöttek, felszámolják a nyilvánvalóan a rendszer megdöntésére készülő kommunista mozgalmat. Még az éjszaka elrendelték és végrehajtották több tucat kommunista vezető letartóztatását, másnapra pedig nagy munkásgyúlést hívtak össze. Ezen 100, talán 150 ezer ember tüntetett az erőszak ellen; a szocdem párt által megmozgatott tömeg éppen százszorosa volt az előző napi kommunista csőcseléknek. A menet élén a szocialista mészárosok haladtak, véres kötényben, hatalmas húsvágó bárdokkal... Ők sem tudhatták, hogy hiába az imponáló demonstráció, a demokratikus intermezzo a végéhez közeledik. A börtönben ugyanis néhány elkeseredett rendőr nekiesett Kun Bélának, az esetről értesült a sajtó, és a félig agyonvert Kunt megkínzott Krisztusként mutatta be egy egész oldalas, hatásvadász riport, amelyet másnap Az Est nagy reklámmal, százezres példányszámban öntött az utcára. ${ }^{105}$ Bár a közhangulatra is befolyással volt a szenzáció, Kun gyorsan gyógyuló sérülései leginkább a kormány maradék cselekvési szabadságát sorvasztották el. A galileista diákok felháborodottan tiltakoztak a rendőri brutalitás ellen, Károlyi Mihályné férje testőrparancsnokával meleg gyapjútakarókat küldetett a „szegény raboknak”, maga Károlyi pedig felháborodottan utasította Váry Albert föügyészhelyettest, hogy vegye le a rabruhát a „politikai foglyokról”. Amikor a berni kongresszusról hazatérő Kunfi Zsigmond újra megjelent minisztertársai körében, kijelentette: ha itt lett volna, a letartóztatásokra nem kerülhetett volna sor. ${ }^{106}$ Néhány napon belül a kommunisták akciószabadsága lényegében helyreállt, Lukács György a Fővárosi Könyvtár egyik kisebb szobájában gyűjtötte össze a „második garnitúrát”, könyvmoly és álmodozó fiatalokat, akikkel újjászervezték a pártot az eredeti vezetők letartóztatása után. ${ }^{107}$ A pártörténet nem nagyon hangsúlyozta ki, de az első napok ijedtségén a nők hamarabb túl voltak, mint a férfiak. Ök nem csupán a könyvtárak csendes íróasztalain írták ki magukból lázas próféciáikat. Az illegális lakások és találkozóhelyek ügyét, továbbá a Vörös Újság szerkesztőségének tagjai között az öszszeköttetést Spádi Adél, a feministák egyesületének titkára szervezte, a különc somogyi dzsentri lány, Goszthonyi Mária pedig futárként szolgált Szamuely Tibor és Lukács György között. ${ }^{108}$ Nemsokára újra elérhető volt a latyakos pesti aszfalton is

105 Tarjányi Vilmos: Kun Bélát félholtra verték a rendőrök. Az Est, (1919), 46. 6.

106 Berinkey Dénes vallomása a népbiztosok perében 1920. július 30-án, BFL. VII. 5.c 1920-6274, 162. doboz, XLVI doszszié, 2955.

107 Lukács György: Februártól márciusig. Párisi Munkás, 4. (1927), 12. Ünnepi melléklet, 1. Újraközli: 3/b. In Bakó Ágnes - Erényi Tibor - Szabó Ágnes (szerk.): Tanúságtevők. Visszaemlékezések a magyarországi 1918-1919-es forradalmak résztvevôiröl. Budapest, Kossuth, 1978. 304-305.

108 Rákos Ferenc: A KMP második (illegális) Központi Bizottságának munkájáról. Társadalmi Szemle, 14. (1959), 2. 97. Gosztonyi Mária emlékezések [Bárdibükk, 1974. III. 28] PIL 867f, g-167, 3-4. 
néhány hétre Nagyváradra menekített Vörös Újság, Kun Béla pedig a börtönből is tovább bomlasztotta a szociáldemokrata pártegységet. Cellájában a szociáldemokrata párt hangadói, a vasutas szakszervezeti vezető Landler Jenő, a hadügyminiszter Böhm Vilmos, és a Budapesti Katonatanács vezetője, Pogány József, valamint a befolyásos újságíró, Göndör Ferenc, sőt egyes visszaemlékezések szerint Kunfi Zsigmond és Weltner Jakab, a Népszava főszerkesztője is felkeresték. ${ }^{109}$ Feltételeit március 11-én meg is üzente a nyomdász-szakszervezeti vezető, Bogár Ignác útján: szakítani kell az osztály-együttműködéssel, azaz a polgári erőkkel, le kell cserélni a régi közigazgatás tagjait, le kell mondani a területi integritáshoz ragaszkodó politikáról, államosítani kell az üzemeket, a bankokat és a földeket, végre kell hajtani a szekularizációt-azaz az egyházak likvidálását-, és mindenekelőtt sutba kell dobni a demokratikus választásokat. ${ }^{110}$

A pacifista Károlyi mindeközben eljutott a fegyveres honvédelem gondolatához. Február 18-án, a kormány ülésén először jelentette ki, hogy „ha a jog és igazság alapján nem tudjuk, akkor fegyverrel a kezünkben készen kell állnunk arra, hogy létfeltételeinket visszaszerezzük". ${ }^{111}$ Nem pillanatnyi indulatkitörésről volt szó. 1919. március 2-án miniszterei és a szocdem erős emberek társaságában meglátogatta az egyetlen számottevő magyar fegyveres erőt képviselő - az erdélyi katonai kerület parancsnoka, Kratochvil Károly ezredes által harcálló egységgé fejlesztett - Székely Hadosztályt Szatmárnémetiben, már úgy fogalmazott: „[H]a a párizsi békekonferencia [...] Magyarország földarabolása mellett döntene, akkor mi a végszükség esetében még fegyverrel is fölszabadítjuk ezt az országot." ${ }^{112}$ Kratochvil parancsnoksága alatt március közepén 649 tiszt és 12438 fős legénységi állomány szolgált, és tartotta eredményesen az Erdélyt határoló nyugati hágókra és szorosokra épített védelmet. ${ }^{113}$ A helyszín is szimbolikus volt, hiszen a város megszállására decemberben engedélyt kaptak a románok, s az a Kratochvil által talpraállított magyar katonai ellenállásnak köszönhetően volt hónapokkal később is még magyar közigazgatás alatt. Ilyen értelemben Károlyi csapatszemléje egyfajta hadüzenet is volt. ${ }^{114}$ „Riasztó harci be-

109 Hajdu Tibor: Válasz Réti László elvtársnak. Párttörténeti Közlemények, 16. (1970), 4. 187. Böhm Vilmos látogatására 1. Majer Ödön büntetőintézeti tiszt rendőrségi vallomása 1920. január 8. BFL. VII. 18. d. 1919 - 13 - 8784 Károlyi Mihály elleni zárlati ügy, 31.

110 Varga Lajos meggyőzően érvel amellett, hogy a Bogár Ignácnak címzett Kun-levél és a tíz nappal későbbi szociáldemokrata-kommunista megegyezés között felesleges közvetlen oksági összefüggést keresni L. Varga Lajos: Kényszerpályáról tévútra. Szociáldemokraták a Tanácsköztársaságban. Budapest, Napvilág, 2019. 34-37.

111 MNL MOL K27 Minisztertanácsi jegyzőkönyvek 1919. február 18., 23. pont.

112 Az elnök és a hadügyminiszter beszédei Szatmáron a székely katonák közt. Magyarország, 1919. március 4, 2. A látogatáshoz l. Fogarassy László: Az ismeretlen székely hadosztály. In Dankó Imre (szerk.): A Debreceni Déri Múzeum évkönyve 1971. Debrecen, Debreceni Déri Múzeum, 1972. 241.

113 Szent Kereszthegyi Kratochvil Károly: A székely hadosztály 1918-19. évi bolsevistaellenes és ellenforradalmi harcai a székely dicsőségért, Erdélyért, Magyarország területi épségéért és Európáért. [1941] Máriabesnyő, Attraktor, 2017. 46. Vö. Őry Károly: A katonapolitika és a hadsereg-szervezés főbb kérdései az októberi polgári demokratikus forradalom időszakában (II. rész). Hadtörténelmi Közlemények, 18. (1971), 1. 18-19. A Kratochvil által közölt és az Ôry által közölt 8939 fős legénységi létszámadatok különbsége a 39. dandárból eredhet, amelynek két ezredében, két és fél zászlóaljnyi, mintegy 3500 fős létszámtöbbletét Kratochvil hozzászámolta a tulajdonképpeni „Székely Hadosztályhoz” Őry pedig nem.

114 Juhász Nagy Sándor: A magyar októberi forradalom története. Budapest, Cserépfalvi, 1945. 427-428. 
széd" - rettent meg az új hangtól a régi barát, Jászi Oszkár, ütőképes serege azonban nem támadt a románok kiveréséhez. ${ }^{115}$ Károlyi abban bízott, hogy a Böhm Vilmos szociáldemokrata hadügyminiszter által februárban megindított hadseregszervezés 70 ezres hadsereget eredményez április közepére. ${ }^{116} \mathrm{~A}$ terveket a világháború harcterein edzett kiváló vezérkari tisztek, Stromfeld Aurél ezredes és Tombor Jenő alezredes dolgozták ki. ${ }^{117}$ De hiába volt a gondos tervezés - és az ambiciózus elképzelések Pozsony és Kolozsvár visszaszerzésére -, a harcos remények mégis kudarcba fúltak, mert a munkáshadsereg eszméje az önkéntességre és a politikai megbízhatóságra épített, azt remélve, hogy majd a szén- és nyersanyaghiány miatt munka nélkül maradt budapesti nagyüzemi munkások szívesen harcba mennek a Felvidékért és Erdélyért.118 Nem így történt. A szociáldemokrata honvédelem hívószava a magas zsold ígéretével együtt sem volt vonzó a háborús fáradtságtól sújtott országban, az öthetes toborzás eredménye alig 5000 jelentkező lett, a meglévő sorkatonaság fegyelme tovább foszlott, a kaszárnyákból a fegyelmezetlen legénység zömét szabadságolták, miután a felső tisztikart - ezredestől felfelé már korábban nyugdíjazták. ${ }^{119}$ A demokratikus hadsereg antimilitarista forradalmát a katonatanácsok intézményének és az úgynevezett „bizalmi férfiaknak” a rendszere teljesítette be. Ez utóbbiakat titkos szavazással választották, s szerepük szerint biztosítaniuk kellett, hogy „a fegyveres hatalom a népköztársaság megbízható támasza legyen” - arra mindenesetre jók voltak, hogy a tiszti tekintély minimálisra csökkenjen, a közkatonák harci készsége pedig eltűnjön. Soós Károly tábornok, a szegedi katonai kerület parancsnoka 1919 februárjában részeg tüzérek élén indult Soborsinba felszámolni a román nemzetőrségeket. A feszes léptű tábornok és törzskara mögött a legénység teljes rendetlenségben haladt, az ágyúkon lovagolva azok csöveit kardlapozták, félrecsúszott sapkával, Soós és tisztikara pedig inkább nem nézett hátra, sok köszönet úgysem lett volna benne. ${ }^{120}$ A korhangulatra jellemzően Böhm hadügyminiszter hősi halottá azt a 21 éves aradi ezredbizalmit, Fellner Andort nyilvánította, aki a parancsmegtagadó katonák helyett magát lőtte főbe. ${ }^{121}$ Feszült várakozás volt a levegőben, Károlyi Mihály azt tervezte, hogy március 23-án vasárnap Karl Renner osztrák kancellárral személyesen egyeztetik országaik érdekeit - a találkozót Garami Ernő készítette elő -, választási gyűlés választási gyúlést ért a pesti gyárudvarokon és kisvárosi nagyvendéglőkben, és terjedtek a hírek arról, hogy a párizsi békekonferencia hamarosan határozatot hoz a „ma-

115 Litván György (szerk.): Jászi Oszkár naplója 1919-1923. Budapest, MTA Történettudományi Intézete, 2001. 20.

116 Károlyi április 15-i céldátumot jelölt meg, és maga is figyelemmel kísérte a hadseregszervezési erőfeszítéseket. Károlyi Mihály levele Andrássy Gyulához 1919. március 16. In Litván György (szerk.): Károlyi Mihály levelezése I. 1905-1920. Budapest, Akadémiai Kiadó, 1978. 444. Vö. Böhm Vilmos: Két forradalom tüzében. Bécs, Bécsi Magyar Kiadó, 1923. 212-213. Liptai Ervin szerint Stromfeld első tervezete már március 20-ra előirányozta az új hadsereg demarkációs vonalakra való elhelyezését, a régi fegyelmezetlen egységek felváltását. Liptai Ervin: A magyar Vörös Hadsereg harcai 1919-ben. Társadalmi Szemle, (1959), 5. 19.

117 Stromfeld terveihez lásd Fogarassy (1972) i. m. 244.

118 A hadseregszervezés kudarcához lásd Révész Tamás: Nem akartak katonát látni? A magyar állam és hadserege 1918-1919-ben. Budapest, Bölcsészettudományi Kutatóközpont Történettudományi Intézet, 2019. 109-111.

119 Böhm (1923) i. m. 211.

120 Kelemen Béla: Adatok a szegedi ellenforradalom és a szegedi kormány müködéséhez (1919). Szeged, 1923. 328.

121 Juhász Nagy (1945) i. m. 450-451. 
gyar ügyben”. A kormány tagjai tudták, hogy valami készülődik, aradi útján Böhm Vilmos figyelmeztette Gondrecourt francia tábornokot a szerb és román megszállási övezetek között állomásozó francia csapatok parancsnokát, a létrejövő ütközőzóna a románok által már megszállt részeken legyen, mert újabb közlekedési vonalak elvágása a magyarok számára csak „halálzónát” hozna létre. ${ }^{122}$ Nem hallgattak rá.

\section{Epilógus}

Vannak a politika történelmében különlegesen sűrű napok. Sokszor a véletlen teszi őket azzá. 1919. március 20-21-én, 36 óra alatt a magyar történelem olyan fordulatot vett, amely a mai napig mélyen meghatározza a politikai gondolkodásunkat, és mélyen megosztja érzelmeinket. Nem tudjuk pontosan mi történt március 20-a délelőtt 10 óra - amikor Fernand Vix francia alezredes, a november vége óta Budapesten tartózkodó szövetséges katonai misszió vezetője angol, olasz és amerikai kollégáinak kíséretében átadta a párizsi békekonferencia határozatát, amelynek értelmében a magyar csapatokat 200 kilométerrel nyugatabbra kellett visszavonni, a románok viszont 100 kilométerrel előre tolhatták állásaikat - és március 21-én este 10 óra között, amikor a szociáldemokrata párt Erzsébet körúti központi titkárságán megjelent a Gyújtőfogházból frissen szabadult Kun Béla, és szertartásos orosz csókkal üdvözölte régi-új elvtársait, és sor került a szociáldemokraták és a kommunisták képviselőiből álló új párt első közös értekezletére, a Forradalmi Kormányzótanács megalakítására, a proletárdiktatúra kikiáltására. Az események egyik kulcsszereplője, Kunfi Zsigmond néhány nappal később vezércikket írt a Vörös Újságba, s úgy értékelte: „A magyar politikai forradalom nagy részben végrehajtotta a polgárságnak, mint osztálynak lefegyverzését, amennyiben igyekezett kicsavarni a polgári osztály kezéből a hadsereget és a fegyveres erő minden intézményét. [...] Az én megítélésem szerint ezt a történelmi funkciót töltötte be az októberi forradalom óta eltelt fél esztendő." 123 A cikk címe egyébként is beszédes volt: Az egyetlen út. Arra utalt, hogy a proletárdiktatúra szükségszerű fejleménye volt az őszirózsás forradalomnak, „Október” és „Március” összetartozik. Aztán eltelt újabb fél esztendő, az út a bukásba vezetett, Kunfi egy rozzant csónakon menekült át Pozsonyba, s a Magyarországon halálra keresett - és a halált maga is kereső ${ }^{124}$ - Kunfi már azt írta bécsi száműzetésében, hogy március 21-e déli 12 óráig „nem tudta, nem kívánta, s nem akarta, hogy a Tanácsköztársaság kikiáltassék". ${ }^{125}$ Október és március útja újra szétvált. Hasonló - és a korszak iránt érdeklődő olvasó számára sokkal inkább ismert - ellentmondás feszül Károlyi Mihály nyilatko-

\footnotetext{
122 Romsics Ignác: Erdély elvesztése 1918-1947. Budapest, Helikon, 2018. 221-222. Vö. Ormos Mária: Padovától Trianonig. Budapest, Kossuth, 1984. 184.

123 Kunfi Zsigmond: Az egyetlen út. Vörös Újság, (1919), március 28. 1.

124 Kunfi Zsigmond hirtelen meghalt. Pesti Napló, (1929), november 19, 5. vö. Köves-Erényi (1974) i. m. 142.

125 Kunfi Zsigmond: Jegyzetek a diktatúra keletkezéséről. [1919] In Kende János - Sipos Péter (szerk.): Visszaemlékezések 1919-ről. Budapest, Gondolat, 1989. 29.
} 
zataiban a hatalom átadásáról. Károlyi Mihálytól a proletárdiktatúra első reggelén, március 22-én reggel azt közölték az újságok: „Én, mint a Magyar Népköztársaság ideiglenes elnöke, [...] a világ proletáriátusához fordulok igazságáért és segítségéért, lemondok és átadom a hatalmat Magyarország népei proletáriátusának." ${ }^{126}$ Akkoriban a közvélemény jelentős része ebben egy ravasz diplomáciai sakkhúzást, bátor trükköt gyanított az antant ellenében. ${ }^{127}$ Károlyi ugyan szenvedélyes sakkjátékos volt, állítólag március 20-án este is egy Karinthy Frigyessel vívott izgalmas partiba menekült a haza gondjai elől, de a fenti nyilatkozat egyértelmű kifejezése volt: az általa vezetett demokratikus és pacifista kísérlet a történelem sakktábláján mattot kapott. ${ }^{128} \mathrm{~A}$ hatalom átadásáról szóló tézist kezdetben Károlyi is erősítette a „proletár” rendszerhez lojális magatartásával, majd Magyarországról való távozása után a bécsi szocialista napilapban, az Arbeiter Zeitungban 1919. július végén közzétett hosszú cikkében, amelyben úgy nyilatkozott: „[A]láírtam a kiáltványt, amelyben lemondtam és 'a hatalmat átadtam a proletariátusnak,' amely azt valójában már korábban átvette és proklamálta." ${ }^{129}$ Ehhez az állásponthoz egészen 1922-ig ragaszkodott, erről vagyonelkobzási pere első szakaszában benyújtott alperesi perirata is tanúskodik, majd 1922 őszétől a per második szakaszától kezdve élete végéig tagadta, hogy aláírta volna a lemondási nyilatkozatát. ${ }^{130} \mathrm{Ez}$ utóbbi eredeti példánya nincsen meg, de a történelemolvasó nem szereti a megoldatlan rejtélyeket, és ennek köszönhetően ma is táborokra osztja a kérdés a történetírókat és olvasókat egyaránt. Ha aláírta, akkor ő hozta nyakunkra Kun Bélát és a kommunizmust, ha nem írta alá: a történelem áldozata. De a történések idején nem így müködött az események logikája. Azt, hogy a hatalomváltásnak nem volt előre megírt forgatókönyve, Kun Béla 1919. március 27-i Népszavába írt cikke is világosan kifejezte, a korábban „szociálárulóknak” „hazaffy-szocialistáknak” titulált szocdemekkel kötött megállapodást azzal indokolta elégedetlen kommunista talpasaival szemben, hogy a „cselekedetek nem folynak egyenes vonalban, de szükségszerűen ellentétekben mozognak, ami tegnap helytelen, az ma a megváltozott viszonyok között nemcsak helyes, de szükségszerű is". ${ }^{131}$

Valójában a kommunista hatalomátvétel annyira a kommunistákon múlott, és legkevésbé sem Károlyi Mihály szándékán, mint inkább a körülmények mindenféle akaratot megszégyenítő hatalmán. Leginkább pedig azon, amit Kunfi Zsigmond úgy fo-

\footnotetext{
126 Károlyi Mihály: Magyarország népéhez! Népszava, 47. (1919), 69. 1., Károlyi Mihály: Magyarország népéhez! Pesti Napló, 70. (1919), 69. 1. Károlyi proklamációja Magyarország népéhez. Világ, (1919), március 22. 5.; Károlyi Mihály lemondott. Az Ujság, (1919), március 22. 2-3.

127 Vántus Károly 1920. július 5-i vallomása a Népbiztos-perben. BFL VII. 5. c 1920 - 6274, 29. doboz, XXVIII. dosszié, 1492.

128 Halasi Andor: Előszó. In Halasi Andor (szerk.): Pirkadása magyar égnek. Irók emlékezései a Magyar Tanácsköztársaságról. Budapest, Szépirodalmi Könyvkiadó, 1959. 11-12.

129 Az Arbeiter Zeitung 1919. július 25-i számában megjelent nyilatkozatot magyarul kivonatosan - némileg gúnyos kommentárok kíséretében idézték a magyarországi lapok. Teljes szövege magyarul: Károlyi Mihály: Lemondásom története In Károlyi Mihály: Egy egész világ ellen. Budapest, Gondolat, 1965. 484-490.

130 Károlyi Mihály elleni eljárások - Károlyi Mihály ellen vagyoni felelősség megállapítása iránti per, Károlyi 1922 február 22-i előkészítő irata / BFL VII. 2. c. 1921 - 36537, 814 [462]. Az előkészítő irat vonatkozó részét kivonatosan ismerteti: Schönwald Pál: A Károlyi-per. Budapest, Kossuth, 1985. 119.

131 Kun Béla: A pártegységről. Levél az elvtársaknak. Népszava, 38. (1919), 73. 1.
} 
galmazott meg tíz évvel később, hogy „a tanácskormány nemzeti pánikhangulatból jött létre”. ${ }^{132}$ Mindezt csak azért felejtettük el, mert bár a Tanácsköztársaság idején az állami szintre emelt terror igazából anarchiába fúlt, a vörös-, majd a rákövetkező fehérterror gyilkosságainak emléke azóta is kísérti és mélységesen megosztja a magyar társadalmat - és eltakarja azt, hogy az I. világháború katasztrófája évekre öszszeroskasztotta rend uralmát a rendetlenség felett. Az internacionalista Kun Béla és Vörös Hadserege fegyverrel próbálta kiưzni a cseh és román megszállókat Magyarországról - a katonai vereségbe bukott bele a proletárdiktatúra, és nem a nemzeti erők ellenállásába -, de a rend csak azután térhetett vissza a meggyötört Magyarországra, hogy Horthy Miklós, Bethlen István, Teleki Pál és társaik elfogadták az elfogadhatatlant, aláírták a békediktátumot és detronizálták az ország biztonságát a trón viszszaszerzésével veszélybe sodró királyt és dinasztiáját a Habsburgokat, és minden erejüket az immár kisállami Magyarország rendbetételére fordították.

\section{FELHASZNÁLT IRODALOM}

Ablonczy Balázs: Ismeretlen Trianon. Budapest, Jaffa, 2020.

Az alsónémedi vérfürdő. Szózat, 5. (1923), augusztus 26.

Andrássy Antal: A polgári forradalomtól a szocialista forradalomig (1918. ősze). In Kanyar József (szerk.): Somogy megye múltjából - Levéltári évkönyv 19. Kaposvár, Somogy Megyei Levéltár, 1988. 263-298.

Andrássy Gyula: Diplomácia és világháború. Budapest, Göncöl-Primusz, 1990. [1920.]

Apáthy István: Erdély az összeomlás után. Új Magyar Szemle, (1920), 2-3. 149.

Balla Tibor: Katonai alakulatok karhatalmi bevetése Magyarországon az első világháború utolsó évében. A Hadtörténeti Múzeum Értesitője, (2011), 12. 63-73.

Ballagi Ernő: A forradalom és a zsidóság. Egyenlőség, 37. (1918), 47.

Bakó Ágnes - Erényi Tibor - Szabó Ágnes (szerk.): Tanúságtevók. Visszaemlékezések a magyarországi 1918-1919-es forradalmak résztvevöiröl. Budapest, Kossuth, 1978.

Barta Róbert: Magyarország az első világháborúban. In Kollega-Tarsoly István (szerk.): Magyarország a XX. században. I. kötet. Szekszárd, Babits, 1996. 24-76.

Berecz Ágoston: Recepciótörténeti széljegyzet Tara Zahra tanulmányához. Régió, 25. (2017), 2. $43-$ 50. Online: https://doi.org/10.17355/rkkpt.v25i2.160

Bernátsky Kornél: Élmények és meglátások 1914-1925. Budapest, 1926.

Borsányi György: Kun Béla. Budapest, Kossuth, 1979.

Bódy Zsombor: A hétköznapi élet története. Munkás visszaemlékezések a századforduló idejéből. In Bódy Zsombor - Mátay Mónika - Tóth Árpád (szerk.): A mesterségek iskolája. Tanulmányok Bácskai Vera 70. születésnapjára. Budapest, Osiris, 2000. 275-293.

Böhm Vilmos: Két forradalom tüzében. Bécs, Bécsi Magyar Kiadó, 1923.

Bucharin, Nikoláj: Az imperializmus diktatúrájától a proletárdiktatúráig. Budapest, Kommunisták Magyarországi Pártja, 1919.

Buza Barna: Hogy veszett el Magyarország? Budapest, Schimkó Gyula, 1921.

Csíki Tamás: A parasztság „forradalma” 1918-ban. In Bódy Zsombor (szerk.): Háborúból békébe: a magyar társadalom 1918 után. Budapest, MTA Bölcsészettudományi Kutatóközpont Történettudományi Intézet, 2018. 129-150.

132 Kunfi (1974) i. m. 365. 
Dálnoki-Kováts Jenő: A megélhetés drágulása a háború kitörése óta. Közgazdasági Szemle, (1921), 1. 264-289.

Debreczeni-Droppán Béla: 1919 forró tavasza a pesti Múzeumkertben. újkor.hu, 2019. március 21. Online: http://ujkor.hu/content/1919-forro-tavasza-a-pesti-muzeumkertben

Dokumentumok és visszaemlékezések 1918-1919 hősi harcaira. Társadalmi Szemle, (1959), 2.

Dósa Rudolfné: A MOVE megalakulása és tevékenysége az 1918-as polgári demokratikus forradalom időszakában. Hadtörténelmi Közlemények, 15. (1968), 3. 464-485.

Fogarassy László: Az ismeretlen székely hadosztály. In Dankó Imre (szerk.): A Debreceni Déri Múzeum évkönyve 1971. Debrecen, Debreceni Déri Múzeum, 1972. 225-252.

A forradalom szenvedései. Egyenlöség, (1918), november 23. 8.

Garami Ernő: Forrongó Magyarország. Emlékezések és tanulságok. Lipcse-Bécs, Pegazus, 1922.

Gellért Oszkár (szerk.): A diadalmas forradalom könyve. Budapest, Légrády, 1918.

Gömbös Gyula: Egy magyar vezérkari tiszt bíráló feljegyzései a forradalomról és ellenforradalomról. Budapest, 1920.

Hajdu Tibor: Az 1918-as magyarországi polgári demokratikus forradalom. Budapest, Kossuth, 1968.

Hajdu Tibor: Válasz Réti László elvtársnak. Párttörténeti Közlemények, 16. (1970), 4. 186-190.

Hajdu Tibor: Katonák, hivatásos tisztek szerepe a magyar és az orosz forradalmakban (1917-1921). Történelmi Szemle, (2009), 4. 519-539.

Halasi Andor: Előszó. In Halasi Andor (szerk.): Pirkadása magyar égnek. Írók emlékezései a Magyar Tanácsköztársaságról. Budapest, Szépirodalmi Kiadó, 1959. 7-22.

Hatos Pál: Felemás gyász - Tisza István meggyilkolása és a magyar közvélemény 1918-ban. Kommentár, (2018), 2. 12-23.

Hatvany Lajos: Egy hónap története. Esztendő, 1. (1918), 12. 1-167.

Hegedús Loránt: Két Andrássy és két Tisza. Budapest, Athenaeum, 1941.

Illyés Gyula: Kora tavasz. Budapest, Szépirodalmi Könyvkiadó, [1941], 1972.

Jócsák Kálmán: Egy élet a harcok tüzében. Kézirat. PIL 867 f. j-109.

Juhász Nagy Sándor: A magyar októberi forradalom története. Budapest, Cserépfalvi, 1945.

Litván György (szerk.): Károlyi Mihály levelezése I. 1905-1920. Budapest, Akadémiai Kiadó, 1978.

Litván György (szerk.): Jászi Oszkár naplója 1919-1923. Budapest, MTA Bölcsészettudományi Kutatóközpont Történettudományi Intézet, 2001.

Károlyi Mihály: Magyarország népéhez! Népszava, 47. (1919), 69.

Károlyi Mihály: Magyarország népéhez! Pesti Napló, 70. (1919), 69. 1.

Károlyi proklamációja Magyarország népéhez. Világ, (1919), 69. 5.

Károlyi Mihály: Lemondásom története. In Károlyi Mihály: Egy egész világ ellen. Budapest, Gondolat, 1965. 484-490.

Kelemen Béla: Adatok a szegedi ellenforradalom és a szegedi kormány müködéséhez (1919). Szeged, 1923.

Kende János: A szakszervezetek szerepe a Tanácsköztársaság államában. Párttörténeti Közlemények, 20. (1974), 4.

Kenez, Peter: Coalition Politics in the Hungarian Soviet Republic. In Andrew C. Janos - William B. Slottman (eds.): Revolution in Perspective: Essays on the Hungarian Soviet Republic of 1919. Berkeley, Los Angeles, University of California Press, 1971. Online: https://doi. org/10.1525/9780520326187-003

Klestenitz Tibor: Médiaháború 1919-ben: a Déli Hírlap ügye. Médiakutató, (2008), 1. 69-80.

A „kommunisták” és mi. Vas-és Fémmunkások Lapja, (1919), január 2. 1.

Kóbor Tamás: A bolsevizmusról a bolsevizmus alatt. Budapest, Franklin, 1919.

Komáromi János: Jászi Aradon. Új Magyar Szemle, (1920), 1. 31.

Köves Rózsa - Erényi Tibor: Kunfi Zsigmond életútja. Budapest, Kossuth, 1974.

Kratochvil Károly (Szent Kereszthegyi): A székely hadosztály 1918-19. évi bolsevistaellenes és ellenforradalmi harcai a székely dicsőségért, Erdélyért, Magyarország területi épségéért és Európáért. [1941] Máriabesnyő, Attraktor, 2017.

Krúdy Gyula: Orosz hangok. Magyarország, 26. (1919), 76.

Kun Béla: A pártegységről. Levél az elvtársaknak. Népszava, 38. (1919), 73. 1. 
Kun Béla: Válogatott írások és beszédek. I. kötet. Budapest, Kossuth, 1966.

Kunfi Zsigmond: Az egyetlen út. Vörös Újság, (1919), március 28. 1.

Kunfi Zsigmond: Különvélemény a Tisza-pörben. Világosság, (1920), augusztus 18.

Kunfi Zsigmond: Jegyzetek a diktatúra keletkezéséről. [1919] In Kende János - Sipos Péter (szerk.): Visszaemlékezések 1919-röl. Budapest, Gondolat, 1989.

Lengyel József: Visegrádi utca. In Lengyel József: Mérni a mérhetetlent. I-II. kötet. Budapest, Szépirodalmi Könyvkiadó, 1966. II., 7-201.

Liptai Ervin: A magyar Vörös Hadsereg harcai 1919-ben. Társadalmi Szemle, (1959), 5.

Lukachich Géza: Magyarország megcsonkitásának okai. Budapest, Nyukosz, é. n. [1932.]

Lukács György: Februártól márciusig. Párisi Munkás, 4. (1927), 12.

Matvejev, I. V.: Magyar internacionalisták részvétele a szovjethatalom megteremtéséért és megszilárdításáért vívott harcban Szibériában (1917 február - 1921). Századok, 93. (1959), 2-4. 335-355.

Márai Sándor: Finálé. Magyarország, (1918), november 10.

Mészáros Károly: Adalékok a Tanácsköztársaság gazdasági-pénzügyi helyzetének alakulásához, a város és falu közötti termékcseréhez, rekvirálásokhoz. Párttörténeti Közlemények, 8. (1962), 3. 38-61.

Mi a kommunizmus? Testvériség, 2. (1919), 11.1.

Nagy Szabolcs: Egy székely város közállapotai az első világháború végén. A sepsiszentgyörgyi rendőrkapitány 1918. áprilisi felirata a megyei alispánnak. Acta Siculica, (2011), 349-354.

Nemes Dezső: A Kommunisták Magyarországi Pártjának létrejötte és kezdeti tevékenysége. Párttörténeti Közlemények, 28. (1982), 4. 3-62.

A nemzethez. Világ, (1919), 123. 1.

Őry Károly: A katonapolitika és a hadsereg-szervezés főbb kérdései az októberi polgári demokratikus forradalom időszakában. (II. rész.) Hadtörténelmi Közlemények, 18. (1971), 1. 7-35.

Pankovits József: Gramsci és 1917. Háború, forradalmak, olasz kommunizmus, fasizmus. Múltunk, (2017), 4. 214-248.

Perecz László: „Gyönyörú víziója egy igazán emberi világnak” (Lukács György 1919-es kommunizmus-képéről). Magyar Filozófiai Szemle, 33. (1989), 5. 535-549.

Péteri György: A „tudományos üzemvezetés” és a munkásellenőrzés konfliktusa 1919-ben. Történelmi Szemle, 22. (1979), 1. 40-58.

A politikai és gazdasági hatalom. Népszava, (1919), 67. 1.

S. N.: Az új év küszöbén. Sárospataki Református Lapok, 15. (1919), 1. 1-2.

Rákos Ferenc: A KMP második (illegális) Központi Bizottságának munkájáról. Társadalmi Szemle, 14. (1959), 2. 94-99.

Révész Tamás: Nem akartak katonát látni? A magyar állam és hadserege 1918-1919-ben. Budapest, Bölcsészettudományi Kutatóközpont Történettudományi Intézet, 2019.

Ritoók Emma: Évekés emberek. Ritoók Emma visszaemlékezései I. 1914-1919. OSZK Kézirattár F473, I. 234.

Romsics Ignác (szerk.): Dokumentumok az 1918/19-es forradalmak Duna-Tisza közi történetéhez. Kecskemét, Bács-Kiskun Megyei Levéltár, 1976.

Romsics Ignác: Erdély elvesztése 1918-1947. Budapest, Helikon, 2018.

Roper, Michael: Nostalgia as an Emotional Experience in the Great War. The Historical Journal, 54. (2011), 2. 421-451. Online: https://doi.org/10.1017/s0018246x11000082

Ormos Mária: Padovától Trianonig. Budapest, Kossuth, 1984.

Saskeöy József: Az alsónémedi eset. Világ, 14. (1923), 193. 2.

Schönwald Pál: A Károlyi-per. Budapest, Kossuth, 1985.

Schönwald Pál: A magyarországi 1918-1919-es polgári demokratikus forradalom állam-és jogtörténeti kérdései. Budapest, Akadémiai Kiadó, 1969.

Siklós András: Adalékok az Osztrák-Magyar Monarchia belső helyzetéhez 1918 tavaszán és nyarán. Történelmi Szemle, 26. (1983), 1. 1-35.

Siklós András: A Habsburg-birodalom felbomlása, 1918. Budapest, Kossuth, 1987. 
Smoling Béla: Ötven év múltán. [1966], Kézirat a Fővárosi Szabó Ervin Könyvtár Budapest Gyüjteményében, Bq 323/206.

Slezkine, Yurii: The Jewish Century. Princeton, Princeton University Press, 2004. Online: https://doi. org/10.1515/9781400828555

Szamuely Tibor: Riadó. Budapest, Kossuth, 1957.

Szécsényi Mihály: Kalauznők tündöklése és bukása. Budapest, 34. (2011), 8. 31-33.

Szemere Vera: Az agrárkérdés 1918-1919-ben. Budapest, Kossuth, 1962.

Szocializmus vagy „kommunizmus”? Famunkás, (1919), február 1. 1.

Szterényi József: Régi idôk emlékei. Politikai feljegyzések, Budapest, Pesti Könyvnyomda, 1925

Takács Mihály: A forradalom és a református egyház. Sárospataki Református Lapok, (1919), 1. 2-4.

Tarjányi Vilmos: Kun Bélát félholtra verték a rendőrök. Az Est, (1919), 46. 6.

Tengely Adrienn: Magyar egyházak a forradalom korában. Eger, Líceum, 2011.

Tonelli Sándor: A franciák Szegeden: 1918 december - 1920 március. Acta Universitatis Szegediensis: Sectio Geographico-Historica, 7. (1939), 1. 1-63.

Üssétek agyon... Vörös Újság, (1919), február 11. 1.

Varga Jenő: A proletárdiktatúra gazdaságpolitikája. In Varga Jenő: Válogatott írások 1912-1922. Budapest, Kossuth, 1976.

Varga Lajos: Kényszerpályáról tévútra. Szociáldemokraták a Tanácsköztársaságban. Budapest, Napvilág, 2019.

Veres Péter: Számadás. Önéletrajz. Budapest, Püski, 1998.

Wessely László: Egy diák a forradalmakban. In Bakó Ágnes - Erényi Tibor - Szabó Ágnes (szerk.): Tanúságtevők. Visszaemlékezések a magyarországi 1918-1919-es forradalmak résztvevőiröl. Budapest, Kossuth, 1978.

Windischgrätz Lajos: Küzdelmeim. Budapest, Szerzői kiadás, 1920.

Zahra, Tara: The 'Minority Problem' and National Classification in the French and Czechoslovak Borderlands. Contemporary European History, 17. (2008), 2. 137-165. Online: https://doi.org/10.1017/ s0960777308004359

Zalai Katalin: A nők „baljós” térfoglalása. A nők gazdasági mobilizációja az első világháború idején. In Egry Gábor - Kaba Eszter (szerk.): 1916 - a fordulat éve? Budapest, Napvilág, 2017.

Zelenski Róbert: Emlékeim. Budapest, Pallas, 1928.

\section{Levéltári források}

A Barcsi Határszéli Államrendőrség kirendeltségvezetőjének jelentése az Istvándi község Nemzeti Tanácsának tagjai ellen lefolytatott bűnvádi eljárásról 1919. január 20-án, MNL SML Főispáni iratok IV. 401. a. 547/1919.

A bolsevizmus előkészítése és lefolyása Kunhegyesen. Masát Ferenc kunhegyesi ref. lelkész 1921. január 15-i jelentése az 1919-es eseményekről MNL MOL K46 PTI 605.f. II/32 őe, 73-75.

A forradalom lezajlása Nagyszebenben, katonatanácsok 1918. október 30-tól 1918. november 30-ig. A nagyszebeni hadapródiskola ismeretlen nevű tisztjének naplójegyzete. HIL TGY 255. 2.821.

A Magyar Nemzeti Tanács miskolci végrehajtó bizottságának felhívása 1918. november 1-jén. MNL MOL K46 PTI 605f. TAGYOB 8. doboz. II/9a dosszié

A pacsai főszolgabíró jelentése a bolseviki mozgalom története. Pacsa, 1921. október 5. K46 PTI 605 f II635 I. kötet.

Bajáki Ferenc 1920. július 10-i vallomása a Népbiztos-perben. BFL. VII. 5.c 1920-6274, XXXIII. doszszié, 1837-1849.

Berinkey Dénes vallomása a népbiztosok perében 1920. július 30-án, BFL. VII. 5.c 1920-6274, 162. doboz, XLVI dosszié, 2955.

Buza Barna vallomása a népbiztosokperében 1920. augusztus 2-án, BFL.VII.5.c1920-6274.162.doboz, XLVIII dosszié, 3075-3076. 
Böhm Vilmos látogatására l. Majer Ödön büntetőintézeti tiszt rendőrségi vallomása 1920. január 8. BFL. VII. 18. d. 1919 - 13 - 8784 Károlyi Mihály elleni zárlati ügy, 31.

Giczey György százados visszaemlékezése Visszaemlékezések a Nemzeti Hadsereg megalakulásáról 1921. március 28. HIL TGY 2.953.12.

Háry Ferenc újlétai jegyző levele a hadügyminiszterhez 1918. november 8-án, HL Polgári demokratikus forradalom iratai, I.29. 12/1, 294.

Jegyzőkönyv a Nemzeti Tanács Igazságügyi Szaktanácsának 1919. december 19-ei üléséről. MOL K440 PTI 607. 3öe, 20-30.

Károlyi Mihály elleni eljárások - Károlyi Mihály ellen vagyoni felelősség megállapítása iránti per, Károlyi 1922 február 22-i előkészítő irata / BFL VII. 2. c. 1921 - 36537, 814 [462]

MNL HBML IV. B. 917 Hajdú vármegyei nemzeti tanács iratai 1. dob. 38/1918. A debreceni nemzeti tanács távirata a budapesti nemzeti tanácsnak, 1918. november 2.

MNL MOL K27 Minisztertanácsi jegyzőkönyvek 1919. február 18.

MNL MOL K46 PTI 605f. TAGYOB 10. doboz. II/ 19 őe.

MNL MOL K 27. Minisztertanácsi jegyzőkönyvek, 1918. november 8. 10. pont.

MNL MOL K 440 A Magyar Nemzeti Tanács iratai 1918-1919. X1511 6997. doboz (mikrofilmmásolat)

Persián Ádám kormánybiztos visszaemlékezései. PIL 704. f. 12. őe.

Sinkovics Pál, a Nagyszénási Nemzeti Tanács elnökének válasza a Szegedi Nemzeti Tanács panaszára. 1918. november 22. MNL MOL Nemzeti Tanács iratai 1918-1919, K440 X1511 6996. doboz (mikrofilmmásolat)

Szurmay Sándor visszaemlékezése. MNL MOL K440 PTI 607. f. 37. 1.

Vincze Sándor: Az erdélyi forradalom. I-II. PIL 965.f. 1., II.

Vántus Károly 1920. július 5-i vallomása a Népbiztos-perben. BFL VII. 5. c 1920 - 6274, 29. doboz, XXVIII. dosszié, 1492.

Zalavármegyei bolsevik mozgalom története IV. hadügy, MNL MOL K46 PTI 605 f. II/35/II. kötet

\section{ABSTRACT}

\section{Order and Disorder in Hungary Between 1918/1919}

Pál HATOS

After four years of destructive conflict in WWI, on 31 October, Hungary collapsed. The 'chrysanthemum revolution' led by Mihály Károlyi had triumphed on the streets of Budapest and almost everywhere in the countryside. The symbol of the old system, former Hungarian prime minister and dreaded political strongman of the entire Dual Monarchy István Tisza was murdered; chaos and unrest began with violent outbursts of popular discontent. The paper examines how the power vacuum and the burden of the lost war formed and deformed the social order. How revolution and prolonged frustration of the majority of the society triggered social, ethnic and ideological conflicts and how the disorder possessed and dispossessed history, and how this short but crucial period led to the ideological radicalization of important strata of the intelligentsia and the bolshevisation, mainly consisting of some of the returning soldiers, the working class of the great factories and the low income urban population especially in the capital city of Hungary, Budapest.

Keywords: WWI, dissolution of the Austro-Hungarian Monarchy, violence, peasant unrest, revolution and bolshevism, Mihály Károlyi, Béla Kun 